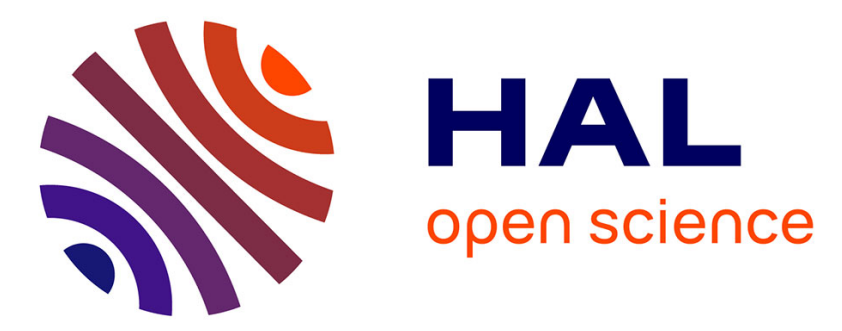

\title{
Fault kinematics and active tectonics at the southeastern boundary of the eastern Alborz (Abr and Khij fault zones): geodynamic implications for NNE Iran
}

Bita Javidfakhr, Olivier Bellier, Esmaeil Shabanian, Lionel Siame, Laëtitia Léanni, Didier Bourlès, Seiran Ahmadian

\section{To cite this version:}

Bita Javidfakhr, Olivier Bellier, Esmaeil Shabanian, Lionel Siame, Laëtitia Léanni, et al.. Fault kinematics and active tectonics at the southeastern boundary of the eastern Alborz (Abr and Khij fault zones): geodynamic implications for NNE Iran. Journal of Geodynamics, 2011, 52 (3-4), pp.290. 10.1016/j.jog.2011.02.005 . hal-00780026

\section{HAL Id: hal-00780026 https://hal.science/hal-00780026}

Submitted on 23 Jan 2013

HAL is a multi-disciplinary open access archive for the deposit and dissemination of scientific research documents, whether they are published or not. The documents may come from teaching and research institutions in France or abroad, or from public or private research centers.
L'archive ouverte pluridisciplinaire HAL, est destinée au dépôt et à la diffusion de documents scientifiques de niveau recherche, publiés ou non, émanant des établissements d'enseignement et de recherche français ou étrangers, des laboratoires publics ou privés. 


\section{Accepted Manuscript}

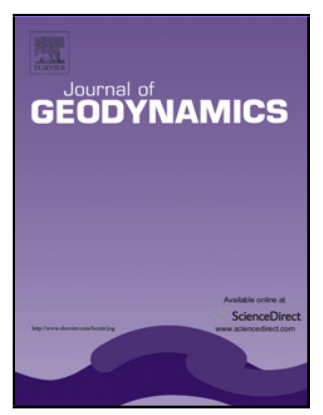

Title: Fault kinematics and active tectonics at the southeastern boundary of the eastern Alborz (Abr and Khij fault zones): geodynamic implications for NNE Iran

Authors: Bita Javidfakhr, Olivier Bellier, Esmaeil Shabanian, Lionel Siame, Laëtitia Léanni, Didier Bourlès, Seiran

Ahmadian

PII:

S0264-3707(11)00041-X

DOI:

Reference: doi:10.1016/j.jog.2011.02.005

GEOD 1048

To appear in:

Journal of Geodynamics

Received date:

$7-7-2010$

Revised date:

$15-2-2011$

Accepted date:

$19-2-2011$

Please cite this article as: Javidfakhr, B., Bellier, O., Shabanian, E., Siame, L., Léanni, L., Bourlès, D., Ahmadian, S., Fault kinematics and active tectonics at the southeastern boundary of the eastern Alborz (Abr and Khij fault zones): geodynamic implications for NNE Iran, Journal of Geodynamics (2010), doi:10.1016/j.jog.2011.02.005

This is a PDF file of an unedited manuscript that has been accepted for publication. As a service to our customers we are providing this early version of the manuscript. The manuscript will undergo copyediting, typesetting, and review of the resulting proof before it is published in its final form. Please note that during the production process errors may be discovered which could affect the content, and all legal disclaimers that apply to the journal pertain. 
Fault kinematics and active tectonics at the southeastern boundary of the eastern Alborz (Abr and Khij fault zones): geodynamic implications for NNE Iran

\author{
Bita Javidfakhr ${ }^{1, *}$, Olivier Bellier ${ }^{1}$, Esmaeil Shabanian ${ }^{1}$, Lionel Siame ${ }^{1}$, Laëtitia Léanni ${ }^{1}$, \\ Didier Bourlès ${ }^{1}$, Seiran Ahmadian ${ }^{2}$
}

${ }^{1}$ Centre Européen de Recherche et d'Enseignement de Géosciences de l'Environnement (CEREGE, UMR CNRS - Aix-Marseille Université, IRD et Collège de France), Université Paul Cézanne, BP 80, 13545 Aix-en-Provence Cedex 4, France.E-mail: bita_javidfakhr@yahoo.com

${ }^{2}$ Islamic Azad University, Shahr-e-Qods Branch, Iran.

*) corresponding author

\begin{abstract}
:
The Alborz is a region of active deformation within the Arabia-Eurasia collision zone. The Abr and the Khij Faults are two NE-trending left-lateral strike-slip faults in the eastern Alborz that correspond to the Shahrud fault system extended through an area of about $95 \times 55 \mathrm{~km}^{2}$. Tectonic landforms typically associated with active strike-slip faults, such as deflected stream channels, offset ridges and fault scarps are documented along the mentioned faults. Detailed analyses of satellite images and digital topographic data accompanied by field surveys allowed us to measure horizontal offsets of about $420 \pm 50 \mathrm{~m}$ and $400 \pm 50 \mathrm{~m}$ for the Abr and Khij faults, respectively. A total of 8 quartz-rich samples were sampled and dated from two different fan surfaces using in situ-produced ${ }^{10} \mathrm{Be}$ cosmogenic dating method. Minimum exposure ages for the abandonment of the alluvial fan surfaces of $115 \pm 14 \mathrm{kyr}$ along the Abr Fault and of $230 \pm 16$ kyr along the Khij Fault imply that both faults are active

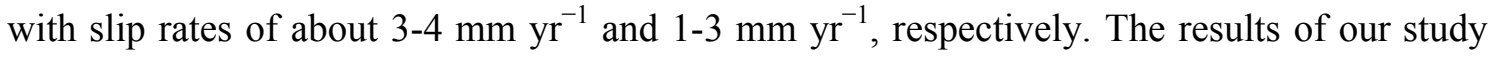
provide the first direct quantitative geological estimates of slip rate along these two active
\end{abstract}


faults and place a new constraint on slip distribution between the faults in the eastern Alborz. Fault kinematic studies (from fault slip data) indicate a $\mathrm{N} 35^{\circ} \mathrm{E}$-trending maximum stress axis comprising a dominant strike-slip regime in agreement with the geomorphological analyses. The left-lateral strike-slip faulting along the Abr and Khij faults and their associated fault zones in the eastern Alborz can be due to the westward component of motion of the South Caspian Basin with respect to Eurasia and Central Iran.

Keywords: Alborz; active tectonics; Abr Fault; Khij Fault; cosmic ray exposure dating; slip rate

\section{Introduction}

Iran is located within the Alpine-Himalayan orogenic belt in a zone of continental convergence between Eurasia to the North and Arabia to the South which is mostly accommodated by shortening and strike-slip faulting in the mountain belts such as the Great Caucasus, Zagros, Alborz, Kopeh Dagh and also the active Makran subduction zone. Recent geological studies indicate that the Arabia-Eurasia collision in Iran occurred between late Eocene and late Oligocene time (e.g., Allen et al. 2004; Agard et al., 2005; Vincent et al., 2005; 2007; Allen and Armstrong, 2008; Fakhari et al., 2008; Horton et al., 2008; Boulton et al., 2009). The Arabia-Eurasia convergence rate is reported to be about $22 \mathrm{~mm} \mathrm{yr}^{-1}$ at the longitude of Bahrain south of the Persian Gulf (Sella et al., 2002; McClusky et al., 2003; Vernant et al., 2004a; 2004b; Reilinger et al., 2006).

The Alborz accommodates the motion between the South Caspian Basin (SCB) and Central Iran (Figure 1A). The Alborz range has evolved from the Triassic to the present-day during the Cimmeride and Alpine Orogenies (Alavi, 1996). The last major tectonic event that led to widespread deformation in northern Iran and the SCB is coeval with middle Miocene to Recent collision-related compression (e.g., Sengor \& Kidd, 1979; Berberian \& Berberian, 
1981). The south Caspian shorelines move northwest at a rate of about $5 \mathrm{mmyr}^{-1}$. The Central Iranian block is defined by internal deformation velocities smaller than $2 \mathrm{~mm} \mathrm{yr}^{-1}$ (Vernant et al., 2004b). The Central Iran northward velocities at the longitudes of Damghan and Jajarm have been reported to be of about $9 \mathrm{~mm} \mathrm{yr}^{-1}$ and $7 \mathrm{~mm} \mathrm{yr}^{-1}$, respectively (Masson et al., 2007). According to Masson et al. (2007), at the longitude of Tehran, the Alborz mountain range accommodates a motion rate of about $6 \mathrm{~mm} \mathrm{yr}^{-1}$ which is in agreement with the results obtained from regional GPS network in the Alborz (Vernant et al., 2004b). The left-lateral shear across the Alborz is constrained to $\sim 4 \mathrm{~mm} \mathrm{yr}^{-1}$ (Vernant et al., 2004a). The large amount of geological, geodetic, geomorphological and geophysical data available for the Alborz allows characterizing and qualifying the deformation of this complex zone (e.g., Axen et al., 2001; Jackson et al., 2002; Allen et al., 2003a; Masson et al., 2006; 2007; Guest et al., 2006a; 2006b; 2007; Ritz et al., 2006; Ritz, 2009; Tatar et al., 2007; Ballato et al., 2008; Landgraf et al., 2009; Nazari et al., 2009; Hollingsworth et al., 2010; Solaymani Azad et al., 2011). The N-S convergence of Central Iran together with the SW-ward motion of the SCB toward Central Iran results in a NNE-trending transpressional tectonic regime in the Alborz mountain range. This transpression could have initiated between 3 and 7 m.y. ago (Ritz et al., 2006).

The Kopeh Dagh mountain range includes Mesozoic and Tertiary sediments, which were folded during the Oligo-Miocene orogenic movements (Stocklin, 1968; 1974; Afshar Harb, 1979; Lyberis \& Manby, 1999). The right-lateral Main Kopeh Dagh Fault system (MKDF) is characterized as the northwestern boundary of the Kopeh Dagh range (Figure 1) and considered as a seismically active structure (Trifonov, 1978). Previous studies (Regard et al., 2005; Authemayou et al., 2006; 2009; Le Dortz et al., 2009; Shabanian et al., 2009a; 2009b) proposed estimates of long-term slip rates for some of the major active fault systems in Iran. A total slip rate of $9 \pm 2 \mathrm{~mm} \mathrm{yr}^{-1}$ is proposed for strike-slip faulting in the Kopeh Dagh, 
resolving for western Kopeh Dagh as an average northward and westward slip rates of about 8 and $4 \mathrm{~mm} \mathrm{yr}^{-1}$, respectively (Shabanian et al., 2009a).

The South Caspian Basin behaves as a relatively rigid aseismic block (Priestley et al., 1994) and is suggested to be a trapped oceanic remnant (Berberian, 1983). This implies that uplift of the high Alborz and Talesh mountains loaded the SCB, causing accumulation of thick late Cenozoic deposits (Axen et al., 2001; Allen et al., 2003b). The SCB is surrounded by orogens including the Great Caucasus, Alborz, Kopeh Dagh, and the Great Balkhan. Based on the motion of a single GPS site on the Caspian shoreline, the SCB moves northwest with respect to Eurasia at a rate of $6 \pm 2 \mathrm{~mm} \mathrm{yr}^{-1}$ and the motion across the central Alborz is suggested to be roughly $5 \pm 2 \mathrm{~mm} \mathrm{yr}^{-1}$ of N-trending shortening and $4 \pm 2 \mathrm{~mm} \mathrm{yr}^{-1}$ of leftlateral strike-slip (Vernant et al., 2004b). A higher estimate of $11 \pm 2 \mathrm{~mm} \mathrm{yr}^{-1}$ has been proposed for the South Caspian-Eurasia motion by Copley \& Jackson (2006). Ritz et al. (2006) mentioned Pleistocene as the age of the SCB northward motion towards Eurasia and suggest that this may have caused not only the change from a compressional tectonic regime to a transpressional one but also the transtension in the internal parts of the range. They emphasize that the internal domain of central Alborz is affected by an active transtensional regime with a WNW-trending extensional axis.

In the current study we present a morphotectonic analysis along two NE-trending leftlateral strike-slip faults, i.e., the Abr and Khij faults (Figure 2) which belong to the Shahrud fault system affecting the eastern Alborz. The determination of the kinematics of the active deformation along the Shahrud fault system using fault slip vectors measured in the field combined with the determination of the abandonment age of two alluvial fan surfaces offset along the faults using in situ-produced cosmogenic ${ }^{10} \mathrm{Be}$ exposure dating of quartz pebbles allow us to establish the rate and kinematics of the late Quaternary deformation in the southeastern limit of the eastern Alborz. At the regional scale, tectonic implications of the 
new data and deduced results presented in this paper provide new geological constraints on active tectonics of the Alborz Mountains.

\section{Seismo-tectonic setting and structural framework}

\subsection{Tectonics}

The Alborz is located south of the SCB consisting late Precambrian to Quaternary deposits (Figure 1A). Tectonic evolution of the Alborz range results from a combination of thrust activity within the orogen and, based on the chronology of the foreland basin deposits (Ballato et al., 2008), of frontal accretion. There are different ideas about the geometry and kinematics of faulting in the Alborz range (e.g., Jackson et al., 2002; Allen et al., 2003a; Guest et al., 2006a; Ritz et al., 2006, Zanchi et al., 2006; Yassaghi et al., 2008; Landgarf et al., 2009). For instance, Ritz et al. (2006) indicated that the margins of Alborz are affected by a transpressional regime, while there is a general left-lateral shear inside the central Alborz range. They have interpreted the total kinematic view of the Alborz as a general strike-slip regime with a change in the position of $\sigma_{1}$ from a horizontally NNE-trending to a vertical one between the margins and the internal domain.

The compressive deformation has been active since Oligocene (Allen et al., 2003a; 2003b). There are active faults along the southern part of the mountain belt and also along the Caspian coast (Bachmanov et al., 2004). The present-day tectonic framework of the range is characterized by a NE-SW compression causing a lateral inversion of the sense of motion from right to left-lateral (Allen et al., 2003a) as well as the activation of ESE-trending thrust faults. Late Cenozoic tectonics in the eastern Alborz is characterized by oblique and strikeslip faulting which reactivated inherited Mesozoic structures. The active tectonic framework of the eastern Alborz consists of major NE-trending left-lateral faults. One of the main structures in northern margin of the Alborz range is the Khazar Fault extended in western part 
of our study area (Figure 1). In eastern part of the Alborz range, the Gorgan Schists are thrusted against Quaternary deposits by the Khazar Fault.

\subsection{Seismicity}

A global record of strain distribution over the last century is available by instrumentally recorded earthquakes, but the interval times between seismic events on individual faults can be up to several thousands of years. Following, we summarize the most important historical and instrumental earthquakes in the eastern Alborz.

A relatively complete catalogue of the historical earthquakes in north-eastern Iran is available (Tchalenko, 1975; Ambraseys \& Melville, 1982; Berberian \& Yeats, 1999; 2001). The largest earthquakes in eastern Alborz are reported in 856, 1825, 1890, 1953 and 1985 with magnitudes ranging from 6.2 to 7.9 (based on the macroseismic data). 200,000 persons were killed in the catastrophic earthquake of 856. According to a recent paleoseismology study in eastern Alborz (Hollingsworth et al., 2010), the Astaneh Fault's rupture is consistent with rupture during the historical 856 A.D. Qumis (Ambraseys \& Melville, 1982) earthquake in NE Iran. Historical earthquakes are also reported in 874, 1436, 1470 and 1498 in the area of Gorgan and Gonbad-Kavous. The destructive earthquakes of 1890 in the Shahrud region could be concerned with the active faults of this study on the basis of the reported regions of maximum destruction (Ambraseys \& Melville, 1982). The earthquake of 1944 caused major damage in Gorgan (Ambraseys \& Melville, 1982). A left-lateral faulting has been involved in the Karnaveh earthquake of 1970 (Mw 6.4), based on the analysis of its aftershock zone (Jackson \& Fitch, 1979). The earthquake of 1985 occurred in the northern part of the Abr Fault (Table 1, Figure 1B).

According to morphotectonic and paleoseismologic studies (Hollingsworth et al., 2010) frequent stream offsets along the trace of the Astaneh Fault (eastern Alborz) may record the 
cumulative offset of the last two to five earthquakes in Holocene. We emphasize that eastern Alborz is more seismically active than western Alborz. Few earthquakes occurred in the SCB and it is thus considered seismically relatively quiet although it is surrounded by very active fault zones (e.g., Priestley et al., 1994).

\section{Shahrud Fault System}

The 400-km-long Shahrud fault system is characterized by active NE-trending left-lateral strike-slip fault zones (Astaneh, Shahrud, Abr and Jajarm fault zones) extending at the SE flank of the eastern Alborz. The combined geomorphic characteristics suggest coeval strikeslip and reverse faulting mechanism for the ongoing activity of this fault system, characterizing a transpressional tectonic regime that is confirmed by the kinematic inversion results (Javidfakhr, 2010).

The left-lateral Astaneh fault zone (the westernmost part of Shahrud fault system) cuts across the topography north of Damghan city. This NE-trending fault zone runs across the southern boundary of eastern Alborz for over $150 \mathrm{~km}$ (Hollingsworth et al., 2008; 2010). Western part of Shahrud fault system includes the Shahrud fault zone defined by two active faults, the 130-km-long Shahrud Fault and the 70-km-long Tazareh Fault (Figure 2). The geomorphic expression of the Shahrud Fault is characterized by abrupt fronts of the mountain range. The high-angle Shahrud Fault is a combination of the E- and NE-trending fault segments running along the eastern Alborz Mountains.

Eastern part of the Shahrud fault system consists of multiple fault zones: (1) the Jajarm fault zone which is an extended fault zone in this broad fault system, (2) the Cheshmeh-Nik fault zone which, at a first glance, seems to be the continuation of the Abr fault (Figure 2). However, this is not certain given the gap visible on satellite images of about $1 \mathrm{~km}$ between them at the eastern termination of the Abr Fault. the southern part of Shahrud fault system can 
be described as the northern margin of Central Iran. The Jajarm Fault is a left-lateral strikeslip fault located in the north of Jajarm city running for about $150 \mathrm{~km}$ in the NE direction (e.g., Hollingsworth et al., 2008; Javidfakhr, 2010). The active Jajarm Fault passes through Quaternary and Plio-Quaternary deposits in most of its trace. The Jajarm Fault is parallel to another left-lateral fault segment along its north side, i.e., Cheshmeh-Nik Fault (Figure 2). The area between the Jajarm and Cheshmeh-Nik faults is covered by Neogene continental red beds and Jurassic limestones as well as scattered Quaternary deposits. The Abr and Khij faults are two active boundary faults, located in the central part of the Shahrud fault system, that have separated the mountainous Alborz region from Central Iran.

\subsection{The Abr fault zone}

The geomorphic expression of the fault zone in the context of the obtained fault kinematic data suggests a reverse component of faulting in the Abr fault zone. The Abr Fault extends for about $95 \mathrm{~km}$ in the eastern Alborz and runs northeast between Nekarman and Tilabad villages (Figures 2B, 3A). The NE-trending Abr Fault is a left-lateral strike-slip fault with a reverse component of dip-slip that marks a distinct topographic boundary between mountainous regions and Quaternary basins (Figure 3E), displaying morphological evidence of active faulting (Figures 3C and 3D). The deflection of rivers across this segment of the Abr Fault suggests this segment has been active in the Quaternary (Figure 3C).

The Abr Fault is parallel to the Khij Fault in most parts of its length, with a spacing of $\sim 20 \mathrm{~km}$ between them. The trend of the Abr Fault changes in its $40 \mathrm{~km}$ long eastern segment and turns to the East. In the termination zone of the Khij Fault, near Tilabad village, the spacing between the two faults decreased to $2 \mathrm{~km}$ due to a change in the orientation of the Abr fault trace (Figure 3A). 
There are no geometric and/or structural changes at fault terminations. At the termination zone, relative fault displacement reduces to zero and is transferred to other structures, laterally or vertically, away from the fault end-point (Legg et al., 2004). The process of fault termination depends on scale since faults interact with various features of different length scales and since also the length scale of a fault increases during fault growth (Alessio et al., 2004). The trend of the Abr Fault changes noticeably in a relatively wide area of its western termination zone (Figure 3B). The Quaternary trace of the Abr Fault terminates in a cluster of distributed small faults within a horsetail structure arrangement (Figure 3B).

There is a 12-km-long active reverse fault in the south of Nekarman village parallel to the trace of the Abr Fault (Figure 4A). The outcrop of this fault was limited to few sites. Vertical offset was estimated from the profile perpendicular to the fault trace which is shown in Figure 4B. The vertical offset of this fault is estimated at about $24 \mathrm{~m}$ (Figure 4C) using the 1:20,000 topographic map.

\subsection{The Khij fault zone}

The left-lateral Khij Fault passes through Khij village (Figure 3A), and strikes NE, parallel to the eastern Alborz range for about $55 \mathrm{~km}$. The trend of the Khij Fault remains constant all along its trace. At its both ends, the trace of the fault remains sharp. There are some nearly parallel small faults $(10-15 \mathrm{~km})$ in the central and western part of the fault. These faults offset the associated terraces left-laterally for several tens of meters (Figure 3D). They probably should be responsible for a negligible part of left-lateral slip across the fault zone. Some channels in the western part of the Khij Fault are deflected with left-lateral offsets of about 20-100 m (Figure 3D). Vertical deformations such as small scarps with reverse faulting arise along the Khij Fault, but most of the features are locally observed and result from strikeslip faulting. 


\section{Fault kinematic analysis}

\subsection{Methodology}

The kinematic measurements were numerically processed to analyze the fault population data (Carey and Brunier, 1974; Carey, 1979), a mean best-fitted deviatoric stress tensor for a fault population being calculated through the minimization of the angular deviation between the measured striation and the resolved shear stress. This inversion method assumes that the slip established by the striation is in the same direction as the resolved shear. The orientation of the principal stress axes $\left(\sigma_{1}, \sigma_{2}, \sigma_{3}\right)$ and the stress ellipsoid shape parameter $(\mathrm{R})$, defined as $\mathrm{R}=\left(\sigma_{2}-\sigma_{1}\right) /\left(\sigma_{3}-\sigma_{1}\right)$, are the results thus obtained through the applied inversion method (Carey and Brunier, 1974; Mercier et al., 1991; Bellier and Zoback, 1995).

Relative chronology of the striations and their coherence with the regional tectonic events are considered to separate the distinct families of striation. We detected two slip generations of striations revealed by clear crosscutting striations on fault planes in most of the measurement sites. Just one slip direction on a given fault plane can be produced by a distinct stress deviator $\left(\sigma_{1}, \sigma_{2}, \sigma_{3}\right.$ and $\left.\mathrm{R}\right)$ due to the assumptions of the fault kinematic inversion methods. Three successive stress states are distinguished through analysis of distinct datasets after the separation of the slip generations (Javidfakhr, 2010).

\subsection{Modern state of stress deduced from the fault kinematic analysis}

The modern state of stress was analyzed using fault kinematics indicated by the last generation of striation sets measured mostly in Quaternary deposits (Table 2). Table 2 consists of the inversion results of the fault slip data accompanied by the lithology definition of different sites. It shows that $\mathrm{R}$ values (that must lie between 0 and 1) are in the range 0.63 to 0.98 . All the tensors representative of the modern stress state indicate the same direction of 
$\sigma_{1}$ stress axes despite different formation ages. For example, the trend of $\sigma_{1}$ at site number 1 comprising Cretaceous age limestone is similar to that at other sites measured in Quaternary or Neogene deposits. Figure 5 indicates the location of the measurement sites and the state of stress deduced from fault kinematics inversion. According to the inversion results for a major part of sites, the modern stress state is characterized by a NE-trending $\sigma_{1}$ ranging from $\mathrm{N} 14^{\circ} \mathrm{E}$ to $\mathrm{N} 46^{\circ} \mathrm{E}$ and indicates a relatively homogeneous stress field.

It is nevertheless possible to distinguish two specified regimes in the studied region. 9 out of 11 sites indeed show strike-slip regimes (with a minor reverse slip component) while two sites (Figure 6, sites number 1 and $8 \mathrm{~B}$ ) indicate mostly compressional stress regime. The inversion results obtained from five measurement sites along the Abr Fault trace characterized a relatively homogenous transpressional stress regime (Figure 5). At site number 8 , two diagrams of inversion solution with $\sigma_{1}$ trending $\mathrm{N} 66^{\circ} \mathrm{E}$ and $\mathrm{N} 12^{\circ} \mathrm{E}$ for the diagram $8 \mathrm{~A}$ and $8 \mathrm{~B}$, respectively (Figure 6), are obtained. However, there is a minor fault almost parallel with the Khij Fault in the vicinity of this number 8 site accompanied by an older fault (almost perpendicular to the trend of Khij Fault) cut by the Khij Fault. This intersection of faults may be the reason of this local variation. Structural framework of the region is thus simply explained by strike-slip and compressional stress deviators (Figure 6). Considering the fault geometry, the dominant left-lateral strike-slip faulting along the Abr and Khij faults is in agreement with an average computed stress deviator, $\mathrm{N} 30^{\circ} \mathrm{E}$ trending horizontal $\sigma_{1}$.

\section{Geomorphic investigations}

\subsection{Methodology: mapping and site selection}

The detailed structure of strike-slip fault zones and their evolution are basic subjects in understanding of the ongoing deformation in this region. Major fault segments have been mapped in order to recognize the structural and geomorphic characteristics of the fault 
system. Different types of satellite images such as LANDSAT ETM+ (14 m resolution), SPOT5 images ( $5 \mathrm{~m}$ resolution) and SRTM data were used to improve the visualization of the traces of the fault systems and better constrain their geometry considering the structural linkage between the different fault segments.

The observation of the recent deposits (Pleistocene until present time) surface morphology allows quantifying the cumulative tectonic displacement which occurred during the last million years. In the current study, sites indicative of distinct fault activity were selected to estimate the fault slip rates. Firstly, the morphology of each site was precisely mapped by combining field observations with evidences from SPOT5 images in order to determine horizontal offsets through examination of the best match possible for the trend of streams incising Quaternary deposits. Study of the segments along the Abr and Khij faults offered evidences for late Quaternary geomorphic features associated with strike-slip faulting, such as stream offsets including tail-cut and head-cut streams and alluvial fan offsets.

\subsection{Offsets}

\subsubsection{Offset of the Abr alluvial fan}

The geomorphic expression along the Abr Fault is characterized by left-laterally offset features such as alluvial fans, stream channels and shutter ridges. Figure 7A shows the morphology of the fan system chosen because it is well preserved from surface outwash and fluvial erosion. In addition to a feeder channel clearly left-laterally offset by the fault, their distinct geomorphology and elevations allow distinguishing five main surfaces. From younger to older, they are classified as Q1 to Q5 (Figure 7B). The geomorphic relationship clearly indicates that the feeder channel was emplaced after the abandonment of the Q3 unit.

Figure 7C shows the geomorphic map of the Abr fan reconstructed to measure the cumulative offsets. With $\sim 700$ m of back-slip, the alignment between the fan's feeder channel 
and the fan axis is restored. The fan's axial channel is beheaded and has a left-laterally offset with respect to its feeder channel. This reconstruction assumes that no rotation occurred. However, some rotation north of the fault zone would only increase the offset by about 20-30 $\mathrm{m}$.

The amount of left-lateral offset ranges from $\sim 60 \mathrm{~m}$ (Figure 7D) for the younger drainages incised in alluvial fans located in the west of the site area to $\sim 700 \mathrm{~m}$ at the dating site (Figure 7C). It seems that the most likely amount of left-lateral offset at this site is $\sim 420$ $\mathrm{m}$ considering the active stream deflection $(\sim 280 \mathrm{~m})$ shown in Figure 7E. However, subparallel faults locating in the area may accommodate additional left-lateral motion across the fault zone.

\subsubsection{Offset of the Khij alluvial fan}

The Khij Fault clearly cuts across the Quaternary surfaces incised by abundant streams in an extended area comprising the dating site (Figure 8A). The strike-slip component dominates the reverse component along the fault (Figures 8b, 9). Along its straight trace, the fault left-laterally offsets the Quaternary landforms such as fan surfaces and river channels (Figure 9).

The restoration of different fan surfaces in the Khij site is difficult due to effects of erosion in the area. Figure 9 illustrates our reconstruction of offsets across the fault zone using the high resolution Quickbird image exhibiting the obvious left-lateral displacement of streams. The actual offset is about $400 \mathrm{~m}$ because the trend of the active drainages is relatively similar in both the upstream and downstream segments (Figure 9). In this area, it is difficult to distinguish the original fan boundaries. We suggest that the uncertainty in offset across the Khij Fault is no more than $50 \mathrm{~m}$ because of the high similarity in trend of the offset features north and south of the fault zone. However, these uncertainties have been considered 
in establishing bounds on the value of offset. Finally, we suggest $400 \pm 50 \mathrm{~m}$ of back-slip to restore the offset, which is the best estimate deduced from the reconstruction of three major offset markers in the proximity of the dating site (Figures 9B, 9C). The displacement of the drainage system is surely younger than the displacement of the fan surfaces. Because the streams incised in the fan surfaces are younger than the fan abandonment, the cumulative offset value of $400 \pm 50 \mathrm{~m}$ is considered as the minimum horizontal offset possible for this segment of Khij Fault. Moreover, digital topography maps with the scale of 1:20,000 were used to determine the vertical displacement across the Khij Fault. Vertical offsets were estimated from the profiles perpendicular to the fault trace after restoring the coeval lateral offset (Figure 8B). The dating site and its surrounding alluvial fans are shown in Figure 8A. The vertical displacement for this segment of the Khij Fault is about $\sim 12 \mathrm{~m}$ (Figure $8 \mathrm{~B}$ ) which represent the prominent strike-slip character of the Khij Fault. The Quaternary surface is gently tilted over Neogene deposits in a site located in the vicinity of Khij dating site (Figure $10)$.

\section{Cosmogenic dating and fault slip rates}

Since the progress made over the last decades by the Accelerator Mass Spectrometry (AMS) technique, cosmogenic nuclides are extensively used to quantify the processes affecting and shaping the Earth's surface (see review in Gosse and Philips, 2001; Dunaï, 2010). In particular, absolute dating of landforms for deciphering climatic history or tectonic history has been more specifically developed and the concepts and principles of the Cosmic Ray Exposure (CRE) dating method relatively well established. Due to its half life of $1.39 \pm$ 0.01My (Korchinek et al., 2009; Chmeleff et al., 2010) and because its production is well known in quartz mineral, in situ-produced ${ }^{10} \mathrm{Be}$ is an adequate candidate to date surface 
samples to 2 My in best conditions (Guralnik et al., 2010) or more frequently from several ky up to $1 \mathrm{My}$ depending of the denudation rate affecting the samples.

Samples were prepared for AMS ${ }^{10} \mathrm{Be}$ measurements following chemical procedures adapted from Brown et al. (1991) and Merchel \& Herpers (1999). Samples were first crushed and sieved. Pure quartz was obtained from the $250-500 \mu \mathrm{m}$ fraction by repeated $\mathrm{H}_{2} \mathrm{SiF}_{6}-\mathrm{HCl}$ etching; atmospheric ${ }^{10} \mathrm{Be}$ was subsequently eliminated by sequential dissolutions with diluted HF. Prior to complete HF digestion of silica, a weighted $100 \mu 1$ of a 3025 ppm home-made carrier solution was added to allow for ${ }^{10} \mathrm{Be} /{ }^{9} \mathrm{Be}$ ratio calculation after AMS measurement. The spiked solutions were finally purified by solvent extractions of Be acetylacetonate in presence of EDTA followed by precipitations of $\mathrm{Be}(\mathrm{OH})_{2}$ at $\mathrm{pH} 8.5$ and rinsing. The final precipitate, dissolved in a few drops of $\mathrm{HNO}_{3}$, is dried and heated at $900^{\circ} \mathrm{C}$ to obtain $\mathrm{BeO}$. Beryllium oxide was mixed to 325 mesh niobium powder prior to measurement at ASTER, the French AMS national facility located at CEREGE, Aix en Provence. All ${ }^{10} \mathrm{Be}$ concentrations are normalized to ${ }^{10} \mathrm{Be} /{ }^{9} \mathrm{Be}$ SRM 4325 NIST reference material with an assigned value of $(2.79 \pm 0.03) \cdot 10^{-11}$. This standardization is equivalent to 07KNSTD within rounding error. The ${ }^{10} \mathrm{Be}$ half-life of $(1.39 \pm 0.01) \times 10^{6}$ years used is that recently recommended by Korschinek et al. (2009) and Chmeleff et al. (2010) according to their two independent measurements. Analytical uncertainties (reported as $1 \sigma$ ) include a conservative $0.5 \%$ external uncertainty based on long-term measurements of standards, a one sigma statistical error on counted ${ }^{10} \mathrm{Be}$ events, and the uncertainty associated with the chemical blanks correction. Two chemical blanks prepared with the samples yield similar ${ }^{10} \mathrm{Be} /{ }^{9} \mathrm{Be}$ ratio of $(3.3 \pm 0.8) \times 10^{-15}$ and $(3.4 \pm 0.7) \times 10^{-15}, 2$ orders of magnitude smaller than the minimum measured ratio. An additional $6 \%$ production rate uncertainty is considered for CRE age calculation (Stone, 2000). 
A modern ${ }^{10} \mathrm{Be}$ production rate at sea-level and high-latitude of $4.5 \pm 0.3$ atoms $/ \mathrm{g} / \mathrm{yr}$, computed for internal consistency from the data of Stone (2000) according to the conclusions of the recently published study on absolute calibration of ${ }^{10} \mathrm{Be}$ AMS standards by Nishiizumi et al. (2007), was used. This sea-level and high-latitude production rate has then been scaled for the sampling altitudes and latitudes using the scaling factors proposed by Stone (2000) because, using the atmospheric pressure as a function of altitude, they take into account the physical properties of cosmic ray particle propagation in the atmosphere and include an improved account for the muonic component in the total cosmogenic production. Corrections for local slope and topographic shielding due to surrounding morphologies following Dunne et al. (1999) appear negligible for both sampling sites.

Erosion is a major source of uncertainty in the surface exposure dating. Considering the very low erosion rate of $0.002 \mathrm{~mm} \mathrm{yr}^{-1}$ estimated for the alluvial fan surfaces of Central Iran using ${ }^{10} \mathrm{Be}$ and ${ }^{36} \mathrm{Cl}$ cosmogenic nuclides (Le Dortz, 2010) and the geomorphic freshness of the Abr and Khij alluvial fans, erosion was reasonably considered as negligible throughout this work. This implies that the CRE ages calculated from the measured ${ }^{10} \mathrm{Be}$ concentrations are minimum exposure ages.

The ${ }^{10} \mathrm{Be}$ concentration in the sampled surface quartz boulders being directly related to alluvial fan abandonment, alluvial fans that have been preserved during left-lateral displacements along the studied faults have been dated in order to estimate their long-term slip rates. Long-term slip rates on strike-slip faults can indeed be obtained by dividing horizontal geomorphic offset by the CRE age of the surface considering the uncertainties associated to the different applied methods.

To minimize the possibility of rotation or rolling, boulders embedded into the ground surface with top surfaces as flat as possible were selected. Even if 6 boulders were collected on each fan, only 3 and 5 samples at the Abr and Khij sites, respectively, provided data 
because the other samples failed through chemical processing due to their unsuitable lithology for ${ }^{10} \mathrm{Be}$ cosmogenic dating. The measured ${ }^{10} \mathrm{Be}$ concentrations and the calculated minimum CRE ages are presented with their associated uncertainties in Table 3.

\subsection{Exposure ages and the slip rate of the Abr Fault}

Along the Abr Fault, in situ-produced ${ }^{10} \mathrm{Be}$ concentration have been measured in samples collected from the Q3 fan surface which has been offset by $420 \pm 50 \mathrm{~m}$ (Figure 7B). Three dated samples yield minimum exposure ages of $96 \pm 6 \mathrm{kyr}, 118 \pm 8 \mathrm{kyr}$ and $131 \pm 9 \mathrm{kyr}$ (Table 3). The observed low dispersion of the Q3 surface ages may result from different rates of exhumation to the surface of sampled boulders that were previously buried within the alluvial deposits. If this is the case, the oldest CRE age yields the more reliable fan surface abandonment age. If this low dispersion results from different erosion rates affecting the surface sampled boulders, the more ${ }^{10} \mathrm{Be}$ concentrated sample yielding the oldest CRE age is the less affected by erosion and thus the sample which again yields the more reliable fan surface abandonment age. Considering then the upper bound of the CRE age series as the more reliable fan surface abandonment age and the horizontal offset of $420 \pm 50 \mathrm{~m}$ recorded by this surface yields a minimum slip rate of $3.2 \pm 0.5 \mathrm{~mm} \mathrm{yr}^{-1}$ along the Abr Fault.

\subsection{Exposure ages and the slip rate of the Khij Fault}

The CRE ages calculated from the in situ-produced ${ }^{10} \mathrm{Be}$ concentrations measured in the five quartz-rich pebbles embedded in the fan surface at the Khij site are generally older than those calculated from the Abr site samples. They indeed range from $152 \pm 10$ to $364 \pm 24 \mathrm{kyr}$. More precisely, three samples, statistically belonging to the same population, cluster around a weighted-mean CRE age of $165 \pm 6 \mathrm{kyr}$ while the two other samples are significantly older (Table 3). The cumulative offset of the fan surface is most likely between 350 and $450 \mathrm{~m}$. 
There is two ways to interpret this observed distribution. Either, as discussed above, erosion can reasonably be considered as negligible and the two older ages result from inherited ${ }^{10} \mathrm{Be}$ acquired during a previous exposure episode in the area. In that case, the weighted-mean ${ }^{10} \mathrm{Be}$ minimum CRE age of $165 \pm 6 \mathrm{kyr}$ is the best estimate for the fan surface abandonment age (Figure 11). Or, the negligible erosion rate assumption is not valid, and the oldest CRE age of $364 \pm 24$ kyr yields the more reliable fan surface abandonment age. In this case, the younger ages result from different erosion processes affecting the fan surface. Considering both interpretations, the cumulative $400 \pm 50 \mathrm{~m}$ horizontal offset recorded by the Khij Fault constrains the Quaternary left-lateral slip rate on this segment of the fault to range between $2.4 \pm 0.3 \mathrm{~mm} \mathrm{yr}^{-1}$ to $1 \pm 0.2 \mathrm{~mm} \mathrm{yr}^{-1}$.

The dated fan has been tectonically uplifted $\sim 12 \mathrm{~m}$ based on quantitative analysis of the slope profile (Figure 8). Taking into account the errors involved in the mean vertical offset measurement and the uncertainties associated to the CRE ages, the vertical slip rate along this segment of the Khij Fault is calculated to be less than $0.07 \mathrm{~mm} \mathrm{yr}^{-1}$.

\section{Discussion and conclusion}

Active deformation in the northeastern boundary of the Arabia-Eurasia collision zone is taken up by strike-slip faults, which is oblique to the convergence direction in this boundary zone (Vernant et al., 2004b; Reilinger et al., 2006). The whole compression in Alborz mountain belt seems to be roughly orientated north-south with a rate of about $8 \pm 2 \mathrm{~mm} \mathrm{yr}^{-1}$ and the shortening rate absorbed by the Alborz and the SCB is about $14 \pm 2 \mathrm{~mm} \mathrm{yr}^{-1}$ (Vernant et al., 2004a).

It is essential to distinguish the present-day tectonic configurations in active deformation domains. This paper focused on a major fault system at the SE boundary of eastern Alborz The major strike-slip faults are mainly located within the internal parts of the Alborz range 
(e.g., Allen et al., 2003a). Active left-lateral strike-slip faults trend ENE and WNW in the eastern (Allen et al., 2003a; Ritz et al., 2006) and western Alborz (Axen et al., 2001; Guest et al., 2006a; 2007), respectively. It is noticeable that there are much more evidences of leftlateral strike-slip faulting in the eastern Alborz (e.g., Hollingsworth et al., 2010) than in the west. Allen et al. (2003a) proposed a model for late Cenozoic structural evolution of the Alborz. They suggested that the continued compressional deformation (probably initiated in Miocene) is accompanied by left-lateral strike-slip faulting along the length of the Alborz range during Plio-Quaternary accommodating the westward motion of the SCB basement with respect to Central Iran.

The ongoing deformation in the Tehran's piedmont (central Alborz) is accommodated along $\mathrm{N} 070^{\circ} \mathrm{E}$ to $\mathrm{N} 110^{\circ} \mathrm{E}$ trending left-lateral strike-slip faults and low angle dip thrusts (Abbassi \& Farbod, 2009). Ritz et al. (2008) estimated a total left-lateral displacement along the active strike-slip faults in central Alborz of about 3-6 km and a cumulative left-lateral displacement of about $3 \mathrm{~km}$ along the central Mosha Fault (central Alborz) is estimated by Solaymani Azad et al. (2011). Based on their recent morphotectonic analysis within central Alborz (Solaymani Azad et al., 2011), the Mosha and North Tehran faults are active leftlateral strike-slip faults displaying a left-stepping en-echelon pattern. Hollingsworth et al., (2010) suggested that frequent stream offsets of 15-20 m along the active trace of the Astaneh Fault could record the cumulative offset of the last two to five earthquakes during Holocene.

The Abr and Khij faults strike parallel to the structural trend of the Alborz range. The trace of the Abr Fault corresponds to the contact between pre-Neogene rock units in north and Quaternary deposits in south. The major neighboring structures such as the Khazar, Shahrud and Jajarm fault zones can significantly influence the fault zone behavior and motion rate in the eastern Alborz. However, the left-lateral motion of the Shahrud fault system and the rightlateral one on the Main Kopeh Dagh Fault are simple explanations for the westward motion of 
western Kopeh Dagh toward the SCB (e.g., Shabanian et al., 2009b). This mechanism is due to the oblique convergence of this boundary zone. The Abr and Khij left-lateral strike-slip faults and their associated faults in the Shahrud fault system are involved in the northward convergence of Central Iran and the north-westwards motion of the SCB relative to Eurasia.

We concentrated on the analysis of geomorphic features to enrich present-day tectonic activity of the region. Alluvial fans can record cumulative displacements in tectonically active regions. Accurate dating of geomorphic offsets can lead us for a quantitative interpretation of long term slip rates on major active faults. It also helps to have a better understanding of the regional tectonics and to establish the deformation history of the area. We have presented evidence of late Quaternary activity along the Abr and Khij fault zones in eastern Alborz. Slip rates are calculated for the strike-slip Abr and Khij faults taking into account the geomorphic evidence and the applied ${ }^{10} \mathrm{Be}$ exposure dating method. A long term left-lateral slip rate of 3.2 $\pm 0.5 \mathrm{~mm} \mathrm{yr}^{-1}$ along the NE-trending Abr Fault has an important implication to our understanding of the deformation in the eastern Alborz. Along the Khij Fault, the horizontal slip rate ranges between $2.4 \pm 0.3 \mathrm{~mm} \mathrm{yr}^{-1}$ and $1 \pm 0.2 \mathrm{~mm} \mathrm{yr}^{-1}$. The vertical slip rate of 0.07

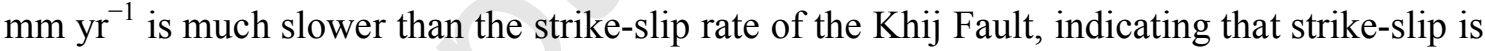
the dominant mechanism of the late Quaternary activity of this fault which is also supported by our geomorphic and fault kinematic data. The absence of clear vertical scarps in the fan deposits is also representative for the dominant component of strike-slip.

In the study area, the active deformation north and east of Bastam city is principally taken up by the Abr and Khij left-lateral strike-slip faults (Figure 2). The Abr fault zone has generated three earthquakes ( $\mathrm{Mw} 4.9-\mathrm{Mw} 6)$ in the past thirty years (Table 1). However, moderate earthquakes could be judged as signals for considerable hazard if they are frequently reported in populated regions. It is fruitful to analyze the earthquake focal mechanisms considering the structural setting of the fault slip data in an extended region to establish more 
precise seismotectonic framework of this boundary zone. The regional stress state $\left(\mathrm{N} 47^{\circ} \mathrm{E}\right)$ is analyzed using the inversion of earthquake focal mechanisms in a vast area between central Alborz and western Kopeh Dagh in $52^{\circ}-56^{\circ} \mathrm{E}$ (Javidfakhr, 2010). This result is in close agreement with the modern stress state deduced from inversion of fault kinematic data. The modern stress field is characterized by a regional NE-trending horizontal $\sigma_{1}$ (Figure 5) based on kinematic inversion results. All the earthquake focal mechanisms are not compatible with this regional stress state. However, we suggest that the complex dynamic characteristics of the study region enclosed between two deformation systems of Alborz and Kopeh Dagh seem to be the most effective factor to characterize the changes in the attitude of $\sigma_{1}$ axis.

Our results can be compared with GPS data that estimate a left-lateral strike-slip motion rate ranging between 2 and $6 \mathrm{~mm} \mathrm{yr}^{-1}$ along the faults in the Alborz (Vernant et al., 2004), to have a better assess to the validity of the results within a regional active deformation framework. It should be noticed that the rate estimate provided by the GPS data, integrates strain over a much larger area.

Detailed geomorphic studies complemented by structural analysis in other parts of the Shahrud fault system will characterize a complete scheme for the geodynamic evolution of this tectonically active zone.

Acknowledgments. This work was funded by the Dyeti and PNRN programs (INSU-CNRS). We would like to thank M. R. Abbassi and M. Zare in International Institute of Earthquake Engineering and Seismology and A. Saidi, M. Ghorashi and M. Talebian in the Geological Survey of Iran for support and logistical assistance. SPOT images were provided thanks to the ISIS program (copyright CNES 2007 to 2008, distribution SPOT images S.A.). We are also grateful to R. Braucher for his help during sample chemical preparations and to the ASTER team for the cosmogenic nuclide concentration measurements (M. Arnold, G. Aumaître, K. 
Keddadouche). The measurements performed at the ASTER AMS national facility (CEREGE, Aix en Provence) are supported by the INSU/CNRS, the French Ministry of Research and Higher Education, IRD and CEA.

\section{References}

Abbassi, M. R., Farbod, Y., 2009. Faulting and folding in quaternary deposits of Tehran's piedmont (Iran). J. Asian Earth Sci. 34, 522-531. doi:10.1016/j.jseaes.2008.08.001.

Afshar Harb, A. 1979, The stratigraphy, tectonics and petroleum geology of the Kopet Dagh region, northeastern Iran, Ph.D. thesis, Petroleum Geology Section, Royal School of Mines, Imperial College of Science and Technology, London.

Agard, P., Omrani, J., Jolivet, L., Mouthereau, F., 2005. Convergence history across Zagros (Iran): constraints from collisional and earlier deformation. International Journal of Earth Sciences 94, 401-419.

Alavi, M., 1996. Tectonostratigraphic synthesis and structural style of the Alborz mountain system in northern Iran. Journal of Geodynamics 21, 1-33.

Allen, M. B., Ghassemi, M. R., Shahrabi, M., Qorashi, M., 2003a. Accommodation of late Cenozoic oblique shortening in the Alborz range, northern Iran. Journal of Structural Geology 25, 659-672.

Allen, M. B., Vincent, S. J., Alsop, G. I., Ismail-zadeh, I., Flecker, R., 2003b. Late Cenozoic deformation in the South Caspian region: effects of a rigid basement block within a collision zone. Tectonophysics 366, 223-239.

Allen, M., Jackson, J. \& Walker, R., 2004. Late Cenozoic reorganization of the Arabia-Eurasia collision and the comparison of short-term and long term deformation rates, Tectonics, 23, TC2008.

Allen, M. B., Armstrong, H. A., 2008. Arabia-Eurasia collision and the forcing of mid-Cenozoic global cooling, Palaeogeography, Palaeoclimatology, Palaeoecology 265 (2008) 52-58.

Alessio, M. A., Martel, S. J., 2004. Fault terminations and barriers to fault growth, Journal of Structural Geology 26, 1885-1896. 
Ambraseys, N. N. \& Melville, C. P., 1982. A history of Persian earthquakes, Cambridge University Press, UK, 219 pp.

Antoine, P., Bahain, J.-J., and G. Berillon, Asgari Khaneghah, A., Tuf calcaire et se'quence alluvial en contexte tectonique actif: La formation de Baliran (province du Mazandaran, Iran), Quaternaire, 17(4), 321-331, 2006.

Authemayou, C., Chardon, D., Bellier, O., Malekzade, Z., Shabanian, E., Abbassi, M., 2006. Late Cenozoic partitioning of oblique plate convergence in the Zagros fold-and-thrust belt (Iran), Tectonics, 25, TC3002, 1-21, doi:10.1029/2005TCOO1860.

Authemayou, C., Bellier, O., Chardon, D., Malekzade, Z., Benedetti, L., Claude, C., Angeletti, B. Shabanian, E. \& Abbassi, M., 2009. Quaternary slip-rates of the Kazerun and the Main Recent Faults: active strike-slip partitioning in the Zagros fold-and-thrust belt, Geophys. J. Int. doi: 10.1111/j.1365-246X.2009.04191.x

Axen, G. J., Lam, P. S., Grove, M., Stockli, D. F., Hassanzadeh, J., 2001. Exhumation of the westcentral Alborz Mountains, Iran, Caspian subsidence, and collision-related tectonics. Geology $29 / 6,559-562$.

Bachmanov, D. M., Trifonov, V. G., Hessami, Kh. T., Kozhurin, A. I., Ivanova, T. P., Rogozhin, E. A., Hademi, M. C., Jamali, F. H., 2004. Active faults in the Zagros and central Iran. Tectonophysics 380, 221-241.

Ballato, P., Nowaczyk, N., Landgraf, A., Strecker, M. R., Friedrich, A. \& Tabatabaei, S. H., 2008: tectonic control on sedimentary facies pattern and sediment accumulation rates in the Miocene foreland basin of the southern Alborz mountains, northern Iran, Tectonics, 27, TC6001.

Bellier, O., Zoback, M. L, 1995. Recent state of stress change in the Walker Lane zone, western Basin and Range province, United States, Tectonics, 14, 564-593.

Berberian, M., 1976. Contribution to the seismotectonics of Iran, part II. Geological Survey of Iran 39, 518.

Berberian, M., and King, G. C. P., 1981. Towards a paleogeography and tectonic evolution of Iran: Canadian Journal of Earth Sciences, v. 18, p. 210-265. 
Berberian, M., 1983. The southern Caspian: a compressional depression floored by a trapped, modified oceanic crust. Canadian Journal of Earth Science 20, 163-183.

Berberian, M., Qorashi, M., Arzhang-ravesh, B., Mohajer-Ashjai, A., 1985. Recent tectonics, seismotectonics and earthquake-fault hazard investigation in the Greater Tehran region: contribution to the seismotectonics of Iran, part V. Geological Survey of Iran 56, 316.

Berberian, M., Ghorashi, M., Shoja Taheri, J., Talebian, M., 1996. Seismotectonic and earthquakefault hazard investigations in the Semnan region, Volume VII: Tehran, Geological Survey of Iran (GSI), p. 268 (in Persian).

Berberian, F., Berberian, M., 1981. Tectono-plutonic episodes in Iran. In: Delany, F.M. (Ed.), ZagrosHindu Kush-Himalaya Geodynamic Evolution. Geodynamics Series. American Geophysical Union, Washington, D.C., pp. 5-32.

Berberian, M. \& Yeats, R. S., 1999. Patterns of historical earthquake rupture in the Iranian Plateau, Bull. seism. Soc. Am., 89, 120-139.

Berberian, M. \& Yeats, R. S., 2001. Contribution of archeaological data to studies of earthquake history in the Iranian Plateau, J. Struct. Geol., 23, 563-584.

Boulton, S. J., 2009. Record of Cenozoic sedimentation from the Amanos Mountains, Southern Turkey: Implications for the inception and evolution of the Arabia-Eurasia continental collision, Sedimentary Geology 216 (2009) 29-47.

Brown, E.T., Edmond, J.M., Raisbeck, G.M., Yiou, F., Kurz, M.D., Brook, E.J., 1991. Examination of surface exposure ages of Antarctic moraines using in situ-produced ${ }^{10} \mathrm{Be}$ and ${ }^{26} \mathrm{Al}$. Geochimica et Cosmochimica Acta 55, 2269-2283.

Carey, E., 1979. Recherche des directions principales de contraintes associées au jeu d'une population de failles, Rev. Geol. Dyn. Geogr. Phys., 21, 57-66.

Carey, E., \& B. Brunier, 1974. Analyse théorique et numérique d'un modèle mécanique élémentaire appliqué à l'étude d'une population de failles, C. R. Acad. Sci., Ser. D, 279, 891-894.

Chmeleff, J., von Blanckenburg, F., Kossert, K., Jakob, J, 2010. Determination of the ${ }^{10}$ Be half-life by multicollector ICP-MS and liquid scintillation counting. Nuclear Instruments and Methods in Physics Research B, 268: 192-199. 
Copley, A. \& Jackson, J., 2006. Active tectonics of the Turkish-Iranian plateau, Tectonics, 25, TC6006.

Dunaï, T.J., Cosmogenic Nuclides. Principles, Concepts and Applications in the Earth Surface Sciences, 2010. Cambridge University Press, New York, ISBN-13 978-0-521-87380-2.

Dunne, J., Elmore, D., Muzikar, P., 1999. Scaling factors for the rates of production of cosmogenic nuclides for geometric shielding and attenuation at depthon sloped surfaces. Geomorphology 27 (1-2), 3-12.

Engdahl, E. R., Jackson, J. A., Myers, S. C., Bergman, E. A. \& Priestley, K., 2006. Relocation and assessment of seismicity in the Iran region, Geophys. J. Int., 167, 761-778.

Fakhari, M. D., Axen, G. J., Horton, B.K., Hassanzadeh, J. \& Amini, A., 2008. Revised age of proximal deposits in the Zagros foreland basin and implications for Cenozoic evolution of the High Zagros, Tectonophysics, 451, 170-185.

Fattahi, M., Walker, R., Hollingsworth, J., Bahroudi, A., Nazari, H., Talebian, M., Armitage, S., Stokes, S., 2006. Holocene slip-rate on the Sabzevar thrust fault, NE Iran, determined using optically stimulated luminescence (OSL), Earth and Planetary Science Letters 245, 673-684.

Guralnik, B., Matmon, A., Avni, Y., Fink, D., 2010. ${ }^{10}$ Be exposure ages of ancient desert pavements reveal Quaternary evolution of the Dead Sea drainage basin and rift margin tilting. Earth and Planetary Science Letters 290 (2010) 132-141. doi:10.1016/j.epsl.2009.12.012.

Geological Survey of Iran, 1990, Quadrangle map of Gorgan, scale1:250,000.

Geological Survey of Iran, 2006, Sheet of Aliabad, scale 1:100,000.

Gosse, J., Phillips, F. M., 2001. Terrestrial in situ cosmogenic nuclides: Theory and application, Quat. Sci. Rev., 20, 1475- 1560.

Guest, B., Axen, G. J., Lam, P. S., Hassanzadeh, J., 2006a. Late Cenozoic shortening in the westcentral Alborz Mountains, northern Iran, by combined conjugate strike-slip and thin-skinned deformation. Geosphere 2 (1), 35-52.

Guest, B., Stockli, D.F., Grove, M., Axen, G.J., Lam, P.S, and Hassanzadeh, J., 2006b, Thermal histories from the central Alborz mountains, northern Iran: implications for the spatial and 
temporal distribution of deformation in northern Iran: Geological Society of American Bulletin, v. 118, p. $1507-1521$.

Guest, B., Guest, A., Axen, G., 2007. Late Tertiary tectonic evolution of northern Iran: A case for simple crustal folding, Global and Planetary Change 58, 435-453.

Hollingsworth, J., Jackson, J., Walker, R., Gheitanchi, M. R., Bolourchi, M. J., 2006. Strike slip faulting, rotation and along-strike elongation in the Kopeh Dagh Mountains, NE Iran. Geophys. $J$. Int. 166, 1161-1177. doi:10.1111/j.1365-246X.2006.02983.x.

Hollingsworth, J., Jackson, J., Walker R., Nazari, H., 2008. Extrusion tectonics and subduction in the eastern South Caspian region since 10 Ma, Geology, v. 36; no.10; p.763-766.

Hollingsworth, J., Nazari, H., Ritz, J-F, Salamati, R., Talebian, M., Bahroudi, A., Walker, R., Rizza, M., Jackson, J., 2010. Active tectonics of the east Alborz mountains, NE Iran: Rupture of the leftlateral Astaneh fault system during the great 856 A.D. Qumis earthquake. JOURNAL OF GEOPHYSICAL RESEARCH, VOL. 115, B12313, doi:10.1029/2009JB007185.

Horton, B. K., Hassanzadeh, J., Stockli, D.F., Axen, G. J., Gillis, R. J., Guest, B., Amini, A. H., Fakhari, M., Zamanzadeh, S. M., Grove, M., 2008. Detrital zircon provenance of Neoproterozoic to Cenozoic deposits in Iran: Implications for chronostratigraphy and collisional tectonics. Tectonophysics $451,97-122$.

Huber, H., Eftekhar-Nezhad, J., 1977. Geological map of Iran, Sheet NO. 1 NE Iran. 1:1000,000, National Iranian Oil Company (NIOC).

Jackson, J., Fitch, T. J., 1979. Seismotectonic implications of relocated aftershock sequences in Iran and Turkey, Geophysical Journal of the Royal Astronomical Society.

Jackson, J., Priestley, K., Allen, M., Berberian, M., 2002. Active tectonics of the south Caspian basin. Geophys. J. Int. 148, 214-245.

Javidfakhr, 2010. Active tectonic analysis in the transition domain between Alborz and Kopeh Dagh (NE Iran). Ph.D. thesis, University of Paul Cézanne (Aix-Marseille III), France, Aix-en-Provence. Korschinek, G., Bergmaier, A., Faestermann, T., Gerstmann, U.C., Knie, K., Rugel, G., Wallner, A., Dillmann, I., Dollinger, G., von Gostomski, Lierse Ch., Kossert, K., Maitia, M., Poutivtsev, M., 
Remmert, A., 2009. A new value for the half-life of ${ }^{10}$ Be by Heavy-Ion Elastic Recoil Detection and liquid scintillation counting. Nucl. Instr. Meth. B. doi:10.1016/j.nimb.2009.09.020.

Lal, D., 1991. Cosmic ray labeling of erosion surfaces: In situ nuclide production rates and erosion models, Earth and Planetary Science Letters, v. 104, p. 424-439.

Lal, D., Chen, J., 2005. Cosmic ray labeling of erosion surfaces II: Special cases of exposure histories of boulders, soils and beach terraces, Earth and Planetary Science Letters 236 (2005) 797-813.

Landgraf A., Ballato, P., Strecker, M. R., Friedrich, A., Tabatabaei, S. H., Shahpasandzadeh M., 2009. Fault-kinematic and geomorphic observations along the North Tehran Thrust and Mosha Fasham Fault, Alborz mountains Iran: implications for fault-system evolution and interaction in a changing tectonic regime, Geophys. J. Int. (2009) 177, 676-690. doi: 10.1111/j.1365246X.2009.04089.x.

Legg, M. R., Kamerling, M. J., Francis, R. D., 2004. Termination of strike-slip faults at convergence zones within continental transform boundaries: examples from the California Continental Borderland.Geological Society, London, Special Publications, 227, 65-82. 0305-8719/04/515.

Le Dortz, K. Meyer B., Sébrier M., Nazari H., Braucher R., Fattahi M., Benedetti L., Foroutan M., Siame L., Bourles D., Talebian M., Bateman M.D. and Ghoraishi M., 2009. Holocene right-slip rate determined by cosmogenic and OSL dating on the Anar fault, Central Iran. Geophys.J. Int., 179, 700-710, doi: 10.1111/j.1365-246X.2009.04309.x

Le Dortz, K., 2010. P.h.D thesis; Cinématique de l'Iran central et oriental: Morphotectonique et datations cosmogéniques et OSL. Uuiversité Pierre \& Marie Curie, Paris 6.

Lyberis, N., Manby, G., 1999. Oblique to orthogonal convergence across the Turan block in the postMiocene. Am. Assoc. Pet. Geol. Bull. 83 (7), 1135-1160.

Masson, F., Djamour, Y., Vangorp, S., Chéry, J., Tavakoli, F., Tatar M. \& Nankali, H., 2006. Extension in NW Iran inferred from GPS enlightens the behavior of the south Caspian basin, Earth planet. Sci. Lett., 252, 180-188.

Masson, F., Anvari, M., Djamour, Y., Walpersdorf, A., Tavakoli, F., Daigni`eres, M., Nankali, H. \& Van Gorp, S., 2007. Large-scale velocity field and strain tensor in Iran inferred from GPS 
measurements: new insight for the present-day deformation pattern within NE Iran, Geophys. $J$. Int., 170, 436-440, doi:10.1111/j.1365-246X.2007.03477.x.

McClusky, S. M., Reilinger, R., Mahmoud, S., Ben Sari, D. \& Tealeb, A., 2003. GPS constraints on Africa (Nubia) and Arabia plate motions, Geophys.J. Int., 155, 126-138.

Merchel, S., Herpers, U., 1999. An update on radiochemical separation techniques for the determination of long-lived radionuclides via accelerator mass spectrometry. Radiochimica Acta, 84: $215-219$.

Mercier, J. L., E. Carey-Gailhardis, and M. Sébrier, 1991. Paleostress determinations from fault kinematics: application to the neotectonics of the Himalayan-Tibet and the central Andes, Philos. Trans. R. Soc. London, Ser. A, 337, 41-52.

Nazari, H., Ritz, J.F., Shafei, A., Ghassemi, A., Salamati, R., Michelot, J.L., Massault, M., 2009. Morphological and paleoseismological analyses of the Taleghan fault, Alborz, Iran. Geophysical Journal International 178, 1028-1041.

Nishiizumi, K., Imamura, M., Caffee, M. W., Southon, J. R., Finkel, R. C., McAninch, J., 2007. Absolute calibration of ${ }^{10} \mathrm{Be}$ AMS standards, Nuclear Instruments and Methods in Physics Research B 258, 403-413.

Priestley, K., Baker, C. \& Jackson, J., 1994. Implications of earthquake focal mechanism data for the active tectonics of the south Caspian Basin and surrounding regions, Geophys. J. Int., 118, 111141.

Raisbeck, G. M., Yiou, F., Bourles, D., Lestringuez, J., Deboffle, D., 1987. Measurements of ${ }^{10}$ Be and ${ }^{26} \mathrm{Al}$ with a Tandetron AMS facility. Nuclear Instruments and Methods B29, 22-26.

Raisbeck, G. M., Yiou, F., Bourlès, D. L., Brown, E., Deboffle, D., Jouhanneau, P., Lestringuez, J., Zhou, Z. Q., 1994. The AMS facility at Gif-sur-Yvette: progress, perturbations, and projects. Nuclear Instruments and Methods in Physics Research B92, 43-46.

Regard, V., O. Bellier, J. -C. Thomas, D. Bourlès, S. Bonnet, M. R. Abbassi, R. Braucher, J. Mercier, E. Shabanian, Sh. Soleymani, and Kh. Feghhi, 2005. Cumulative right-lateral fault slip rate across the Zagros - Makran transfer zone and role of the Minab-Zendan fault system within the convergence accommodation between Arabia and Eurasia (SE Iran), Geophys. J. Int., 160, 1-25. 
Reilinger, R. et al., 2006. GPS constraints on continental deformation in the Africa-Arabia-Eurasia continental collision zone and implications for the dynamics of plate interactions, J. geophys. Res., 111, B05411, doi:10.1029/2005JB004051.

Ritz, J.-F., Nazari, H., Ghassemi, A., Salamati, R., Shafei, A., Solaymani, S., and Vernant, P., 2006. Active transtension inside central Alborz: A new insight into northern Iran-southern Caspian geodynamics: Geology, v. 34, p. 477-480, doi: 10.1130/G22319.1.

Ritz, J. F., 2009. Extrusion tectonics and subduction in the eastern South Caspian region since $10 \mathrm{Ma}$ : Comment, Geology 37, E191-E191.

Sella, G. F., Dixon, T. H., Mao, A., 2002. A model for recent plate velocities from space geodesy, J. Geophys. Res. 107, $11-32$.

Sengor, A .M. C., Kidd, W. S. F., 1979. Post-collisional tectonics of the Turkish-Iranian plateau and a comparison with Tibet. Tectonophysics 55, 361-376.

Shabanian, E., L. Siame, O. Bellier, L. Benedetti, and M. R. Abbassi, 2009a. Quaternary slip rates along the northeastern boundary of the Arabia-Eurasia collision zone (Kopeh Dagh Mountains, Northeast Iran), Geophys. J. Int., 178, 1055-1077, doi: 10.1111/j.1365-246X.2009.04183.x.

Shabanian, E., O. Bellier, L. Siame, N. Arnaud, M. R. Abbassi, and J.-J. Cochemé, 2009b. New tectonic configuration in NE Iran: active strike-slip faulting between the Kopeh Dagh and Binalud mountains, Tectonics, 28, TC5002, doi: 10.1029/2008TC002444.

Shahrabi M., et al., 1990. Geological Survey of Iran, Quadrangle map of Gorgan, scale 1:250,000.

Solaymani Azad, Sh., Ritz, J-F, Abbassi, M. R., 2011. Left-lateral active deformation along the Mosha-North Tehran fault system (Iran): Morphotectonics and paleoseismological investigations. Tectonophysics 497 (2011) 1-14, doi:10.1016/j.tecto.2010.09.013.

Stocklin, J., 1968. Structural history and tectonics of Iran: a review. Am. Assoc. Pet. Geol. Bull. 52 (7), 1229-1258.

Stocklin, J., 1974. Northern Iran: Alborz Mountains. In: Spencer, A. M. (Ed.), Mesozoic-Cenozoic Orogenic Belts; Data for Orogenic Studies; Alpine-Himalayan Orogens. Special Publication. Geological Society of London, London, pp. 213-234. 
Stone, J. O., 2000. Air pressure and cosmogenic isotope production. Journal of Geophysical Research $105,23753-23759$.

Tatar, M., Jackson, J., Hatzfeld, D., Bergman, E., 2007. The 2004 May 28 Baladeh earthquake (Mw 6.2) in the Alborz, Iran: Overthrusting the South Caspian Basin margin, partitioning of oblique convergence and the seismic hazard of Tehran: Geophysical Journal International, v. 170, 249 261.

Tuniz, C., Bird, J. R., Fink, D., Herzog, G. F., 1998. Accelerator Mass Spectrometry; Ultrasensitive Analysis for Global Science, CRC Press, Boca Raton, FL, p. 371.

Vernant, P., Nilforoushan, F., Hatzfeld, D., Abbassi, M. R., Vigny, C., Masson, F., Nankali, H., Martinod, J. , Ashtiani, A., Bayer, R., , Tavakoli, F., Chery, J., 2004a. Contemporary crustal deformation and plate kinematics in Middle East contrained by GPS measurements in Iran and northern Oman, Geophys. J. Int. 157 (2004) 381-398.

Vernant, P., Nilforoushan, F., Chéry, J., Bayer, R., Djamour, Y., Masson, F., Nankali, H., Ritz, J.-F., Sedighi, M., Tavakoli, F., 2004b. Deciphering oblique shortening of central Alborz in Iran using geodetic data. Earth and Planetary Science Letters 223, 177-185.

Vincent, S. J., Allen, M. B., Ismail-Zadeh, A. D., Flecker, R., Foland, K. A., Simmons, M. D., 2005. Insights from the Talysh of Azerbaijan into the Paleogene evolution of the South Caspian region. Bulletin of the Geological Society of America 117, 1513-1533.

Vincent, S. J., Morton, A. C., Carter, A., Gibbs, S., Barabadze, T. G., 2007. Oligocene uplift of the Western Greater Caucasus: an effect of initial Arabia-Eurasia collision. Terra Nova 19, 160-166.

Yassaghi, A., Madanipour, S., 2008. Influence of a transverse basement fault on along-strike variations in the geometry of an inverted normal fault: Case study of the Mosha Fault, Central Alborz Range, Iran, Journal of Structural Geology 30 (2008) 1507-1519.

Zanchi, A., Berra, F., Mattei, M., Ghassemi, M. R., Sabouri, J., 2006. Inversion tectonics in central Alborz, Iran, Journal of Structural Geology 28, 2023-2037. 


\section{Highlight}

$>8$ quartz-rich samples were dated from two fan surfaces using in situ-produced ${ }^{10} \mathrm{Be}$ cosmogenic dating method. > Left-lateral slip rate of $3.2 \pm 0.5 \mathrm{~mm} \mathrm{yr}^{-1}$ is calculated for the Abr Fault. $>$ Along the Khij Fault, the horizontal slip rate ranges between $2.4 \pm 0.3 \mathrm{~mm} \mathrm{yr}^{-1}$ and $1 \pm 0.2 \mathrm{~mm} \mathrm{yr}^{-1}$. $>$ The modern stress state is characterized by a NE-trending $\sigma_{1}$ indicating a relatively homogeneous stress field. $>$ 


\section{Figure captions:}

Figure 1. A. Simplified tectonic map of NNE Iran superimposed on GTOPO30 topographic image. The Khazar Fault (KHF) exists in the boundary zone between the South Caspian Basin (SCB) and Alborz Mountains. The Main Kopeh Dagh Fault (MKDF) forms a topographic boundary between Eurasia and Kopeh Dagh Mountains. The black rectangle in the inset box indicates the location of Figure 1 in the Middle East Alpine Collision belt. White arrows and

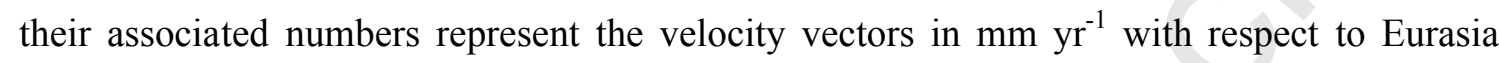
(Reilinger et al., 2006). B. Fault map of the eastern Alborz and western Kopeh Dagh superimposed on 90 m SRTM (Shuttle-borne Radar Topography Mission) image of the area. Earthquake focal mechanisms are mostly based on the Harvard catalogue http://www.globalcmt.org/CMTsearch.html and McKenzie (1972) (see Table 1 for details).

Figure 2. A. Major faults in northeastern Iran superimposed on SRTM image showing leftlateral movement of NE-trending active faults in the Shahrud Fault System. The study area corresponds to the rectangle enlarged in Figure 3.

Figure 3. A. The locations of different sites are identified in this Landsat (14 m resolution) image. Yellow circles are the location of sites where slip rates have been determined by dating of the offset alluvial fans. The abbreviations are as follows: AF: Abr Fault, KHF: Khij Fault. B. SPOT5 (5 m resolution) images focused on areas along the Abr and Khij faults (BE). This Figure shows the enlargement of the termination zone of the Abr Fault. There are multiple small faults splayed in a rather wide area at the termination of the Abr Fault. C. Leftlateral deflection of streams is indicative of left-lateral movement of the Abr Fault. Fan boundaries are shown by dotted lines. D. The sharp escarpment of the Khij Fault which runs between volcanic (mainly Andesites) rocks and Quaternary. E. Three dimension view of the area on the basis of digital topographic maps with the scale of $1 / 20,000$. The squares indicate 
the position of the sampling sites and the fault traces are shown by dotted lines. No altitude exaggeration is exerted in this image.

Figure 4. A. SPOT5 image of a 12-km-long active reverse fault in the south of Nekarman. The dotted white rectangle is enlarged in Figure B. The location and direction view of Figure $6 \mathrm{D}$ is shown by the symbol. The trace of the fault is shown with small arrows. B. Topographic map (10 m contours) of this area is superimposed on the SPOT5 image. The A-B line represents the position of the topographic profile. C. The vertical displacement of the fault is estimated about $25 \mathrm{~m}$.

Figure 5. Structural map of the study area superimposed on the SRTM image, comprising the fault slip measurement sites. Trends of $\sigma_{1}$ (maximum stress axis) for the modern stress regime are presented. Sites are identified by numbers, see Table 2 for details. The inferred fault in the westernmost of the figure represents the Khazar Fault.

Figure 6. Lower hemisphere stereographic projections of the fault plane data together with inversion results determined by the inversion method proposed by Carey (1979). The labels refer to the site locations presented in Figure 5. The large arrows indicate the azimuth of $\sigma_{1}$. A fixed solution (Bellier and Zoback, 1995) was applied to deal with the sites comprising less than four well-distributed fault directions (site number 6). One of the principal stress axes is fixed to remain purely vertical in the fixed inversion method. Measurement sites comprising two tectonic regimes in each state of stress are presented by adding "A" suffix to the identifying number of the site. The suffix " $\mathrm{B}$ " is added to the measurement site number in the cases that the data were not enough and/or well-distributed to be reliable as an inversion solution. Note that the trend of $\sigma_{1}$ is similar in site number 1 comprising the limestone of Cretaceous age with other sites measured in Quaternary or Neogene deposits (refer to Table 2). 
Figure 7. A. SPOT5 image focused on the Abr fan. B. Geomorphic map of Quaternary alluvial fans along the Abr Fault. Distinct surfaces of different ages are shown for the fan, from younger to older (Q1 to Q5). Solid line indicates the fault trace. Small squares show sampling locations on the alluvial fan surfaces. The associated ages are presented for three samples (The other samples did not have enough quartz for the process of in situ exposure ${ }^{10} \mathrm{Be}$ dating). There is an offset between the fan's feeder channel and the actual position of the fan axis. C. A backward slip of about $700 \mathrm{~m}$ restores the alignment of the fan's feeder channel and the fan axis. D: The rectangle area located in the west of the dating site shows left-lateral offset of a smaller stream channel for about $60 \mathrm{~m}$. E. True left-lateral offset is considered about $42 \mathrm{~m}$ taking into account the active deflection of the stream.

Figure 8. A. Topographic contour map (10 m contours) of Khij area displayed over SPOT5 image. A-B represents the position of the cross section. The small squares are indicative of collected samples. B. Topographic profile along the line A-B shows a vertical displacement of about $12 \mathrm{~m}$ along this segment of the Khij Fault. Sampling location and their associated in situ ${ }^{10} \mathrm{Be}$ ages are presented.

Figure 9. A. The Google Earth image (resolution $3 \mathrm{~m}$ ) clearly shows left-lateral displacement along the Khij Fault through stream channel offsets. B and C. left-lateral offset of $\sim 400 \mathrm{~m}$ is achieved for this segment of the Khij Fault. Two fault planes nearly parallel with this segment of Khij Fault are shown in the lower stereographic projections.

Figure 10. A. ENE looking view of the escarpment of the Khij Fault. B. NW looking view of the disconformity between the Quaternary and Neogene layers. The Quaternary surface is tilted and uplifted. This site is located in the vicinity of our dating site.

Figure 11. In situ-produced ${ }^{10} \mathrm{Be}$ exposure ages and their associated uncertainties for the samples collected from the fan surface along the Khij Fault assuming no erosion and no 
inheritance, The black curve indicates the Gaussian age probability sum (Psum) and thin curves represent the age probability for each sample. 
Table 1. Earthquake source parameters.

\begin{tabular}{|c|c|c|c|c|c|c|c|c|c|c|c|c|c|c|}
\hline \multirow{2}{*}{$N^{\circ}$} & \multirow{2}{*}{$\begin{array}{c}\text { Date } \\
\text { (yyyymmdd) }\end{array}$} & \multirow{2}{*}{$\begin{array}{c}\text { Time } \\
\text { (hhmm) }\end{array}$} & \multirow{2}{*}{$\begin{array}{l}\text { Lat. } \\
\left({ }^{\circ} \mathrm{N}\right)\end{array}$} & \multirow{2}{*}{$\begin{array}{l}\text { Long. } \\
\left({ }^{\circ} \mathrm{E}\right)\end{array}$} & \multirow{2}{*}{$\mathrm{Mb}$} & \multicolumn{3}{|c|}{ Plane 1} & \multicolumn{3}{|c|}{ Plane 2} & \multirow{2}{*}{$\begin{array}{c}\text { Depth } \\
(\mathrm{km})\end{array}$} & \multirow{2}{*}{$\mathrm{R}$} & \multirow{2}{*}{ ID } \\
\hline & & & & & & Azimuth & Dip & Rake & Azimuth & Dip & Rake & & & \\
\hline 1 & 19700730 & 0052 & 37.85 & 55.92 & 6.4 & 293 & 56 & -150 & 185 & 66 & -38 & 11 & $P$ & 6 \\
\hline 2 & 19710214 & 1627 & 36.62 & 55.74 & 5.3 & 336 & 39 & 93 & 152 & 51 & 87 & 4 & $P$ & 7 \\
\hline 3 & 19730802 & 2028 & 37.32 & 56.60 & 4.9 & 297 & 10 & 86 & 121 & 80 & 91 & 34 & $M$ & 11 \\
\hline 4 & 19740307 & 1136 & 37.60 & 55.83 & 5,1 & 23 & 89 & -1 & 113 & 89 & -179 & 21 & $\mathrm{JF}$ & 12 \\
\hline 5 & 19790224 & 1356 & 37.22 & 56.66 & 4.7 & 278 & 41 & 56 & 140 & 57 & 116 & 33 & $M$ & 13 \\
\hline 6 & 19791209 & 0912 & 35.15 & 56.87 & 5.6 & 325 & 36 & 99 & 133 & 54 & 83 & 9 & $\mathrm{~J}$ & 15 \\
\hline 7 & 19851201 & 2031 & 37.63 & 56.62 & 4.6 & 281 & 54 & 69 & 134 & 41 & 116 & _ & $M$ & 18 \\
\hline 8 & 19880311 & 0738 & 37.27 & 56.26 & 4.5 & 277 & 43 & 13 & 177 & 81 & 132 & 33 & $M$ & 22 \\
\hline 9 & 19880508 & 0650 & 35.33 & 55.94 & 4.7 & 219 & 87 & 4 & 129 & 86 & 177 & 53 & $M$ & 23 \\
\hline 10 & 19900818 & 0951 & 37.06 & 56.21 & 4.9 & 211 & 77 & -4 & 302 & 86 & -166 & 13 & $M$ & 24 \\
\hline 11 & 19810721 & 0445 & 39.41 & 53.22 & 5.1 & 290 & 87 & -2 & 20 & 88 & -177 & 42 & CMT & 35 \\
\hline 12 & 19830325 & 1157 & 36.65 & 52.62 & 5.2 & 280 & 68 & 5 & 188 & 86 & 157 & 33 & CMT & 36 \\
\hline 13 & 19830326 & 0407 & 35.88 & 52.01 & 5.4 & 104 & 61 & 17 & 6 & 75 & 150 & 10 & СMT & 37 \\
\hline 14 & 19851029 & 1313 & 36.96 & 54.59 & 6.0 & 97 & 31 & 122 & 241 & 64 & 73 & 15 & СMT & 39 \\
\hline 15 & 19870907 & 1132 & 39.13 & 54.87 & 5.5 & 312 & 14 & 106 & 116 & 77 & 86 & 29 & СMT & 41 \\
\hline 16 & 19900120 & 0127 & 35.89 & 53.00 & 5.5 & 97 & 65 & -8 & 190 & 82 & -154 & 25 & $M$ & 42 \\
\hline 17 & 19890913 & 0701 & 37.28 & 54.25 & 5.1 & 262 & 23 & -82 & 74 & 67 & -92 & 38 & $M$ & 43 \\
\hline 18 & 19880113 & 0556 & 37.28 & 54.37 & 4.9 & 287 & 89 & 3 & 197 & 87 & 179 & 33 & $M$ & 44 \\
\hline 19 & 19880508 & 0650 & 35.33 & 55.94 & 4.7 & 219 & 87 & 4 & 128 & 86 & 177 & 53 & $M$ & 45 \\
\hline 20 & 19880823 & 0530 & 35.42 & 52.28 & 5.0 & 15 & 70 & 45 & 266 & 48 & 152 & 35 & $M$ & 46 \\
\hline 21 & 19880823 & 1058 & 35.34 & 52.34 & 4.6 & 163 & 64 & 129 & 226 & 11 & 323 & 38 & M & 47 \\
\hline 22 & 19881024 & 1701 & 35.25 & 52.30 & 4.9 & 331 & 62 & 34 & 223 & 60 & 147 & 34 & $M$ & 48 \\
\hline 23 & 19700730 & 0052 & 37.85 & 55.94 & 5.7 & 33 & 57 & 5 & 300 & 86 & 146 & - & $M$ & 49 \\
\hline 24 & 19851029 & 1313 & 36.74 & 54.81 & 6.0 & 14 & 37 & 26 & 263 & 75 & 124 & 13 & M & 50 \\
\hline 25 & 19840511 & 0958 & 36.71 & 55.00 & 4.9 & 261 & 57 & -130 & 139 & 50 & 44 & 29 & M & 51 \\
\hline 26 & 19840615 & 1850 & 37.21 & 55.39 & 4.4 & 277 & 29 & 40 & 150 & 71 & 113 & _ & $M$ & 52 \\
\hline 27 & 19830326 & 0407 & 36.06 & 52.28 & 5.4 & 31 & 88 & 25 & 300 & 65 & 178 & 33 & $M$ & 53 \\
\hline 28 & 19820515 & 1736 & 35.57 & 54.11 & 4.5 & 96 & 66 & 48 & 342 & 48 & 146 & 13 & $M$ & 54 \\
\hline 29 & 19821025 & 1654 & 35.13 & 52.38 & 4.5 & 185 & 57 & -32 & 294 & 63 & -142 & 44 & M & 55 \\
\hline 30 & 19810809 & 1308 & 36.92 & 55.29 & 4.9 & 256 & 60 & -34 & 6 & 60 & -143 & - & M & 56 \\
\hline 31 & 19770502 & 1517 & 37.06 & 55.33 & 5.1 & 246 & 70 & -24 & 345 & 67 & -157 & 19 & $M$ & 57 \\
\hline 32 & 19760531 & 0807 & 38.91 & 55.85 & 4.7 & 43 & 84 & -147 & 309 & 58 & -6 & 7 & $M$ & 58 \\
\hline 33 & 19740307 & 1136 & 37.65 & 55.95 & 5.2 & 190 & 59 & -30 & 297 & 64 & -144 & _ & $M$ & 59 \\
\hline 34 & 19710214 & 1627 & 36.62 & 55.74 & 5.3 & 231 & 51 & 8 & 136 & 84 & 141 & 4 & $M$ & 60 \\
\hline 35 & 19710809 & 0254 & 36.27 & 52.81 & 5.2 & 77 & 36 & -70 & 234 & 56 & -103 & 12 & M & 61 \\
\hline 36 & 19680519 & 1649 & 36.61 & 53.35 & 4.6 & 254 & 15 & 0 & 346 & 90 & -104 & 22 & M & 62 \\
\hline
\end{tabular}

All angles are presented in degrees and date is as the usual convention (year/month/day). Figure 1B represents the focal mechanisms on the basis of these seismic data. The ID numbers refer to the label of each beachball in Figure 1B. It should be noted that the reported depths for individual earthquakes are not entirely reliable due to a poor azimuthal coverage of the worldwide station network. 
Table 2. The results of fault kinematic inversions.

\begin{tabular}{cccccccccccc}
\hline Site & Longitude $\left({ }^{\circ} \mathrm{E}\right)$ & Latitude $\left({ }^{\circ} \mathrm{N}\right)$ & $\sigma_{1}$ (trend/plunge) & $\sigma_{2}$ (trend/plunge) & $\sigma_{3}$ (trend/plunge) & $\mathrm{N}$ & $\mathrm{R}$ & Quality & Lithology & Age $($ Formation) \\
\hline 1 & 54.832 & 36.379 & $198 / 06$ & $107 / 02$ & $358 / 84$ & 8 & 0.777 & $\mathrm{~B}$ & Limestone & Cretaceous \\
2 & 54.944 & 36.474 & $177 / 10$ & $274 / 36$ & $74 / 52$ & 8 & 0.671 & $\mathrm{~B}$ & Conglomerate & Pl-Q \\
3 & 54.977 & 36.445 & $231 / 24$ & $138 / 06$ & $34 / 65$ & 9 & 0.659 & $\mathrm{~A}$ & Limestone & Pre-Pliocene \\
4 & 55.063 & 36.496 & $188 / 01$ & $279 / 30$ & $97 / 60$ & 5 & 0.640 & CF & Conglomerate & Quaternary \\
5 & 54.842 & 36.533 & $38 / 14$ & $300 / 29$ & $150 / 57$ & 7 & 0.649 & $\mathrm{~B}$ & Conglomerate & Quaternary \\
$6 *$ & 54.913 & 36.578 & $191 / 00$ & $46 / 90$ & $281 / 00$ & 4 & 0.323 & $\mathrm{CF}$ & Alluvial fan & Quaternary \\
7 & 55.076 & 36.703 & $208 / 06$ & $337 / 79$ & $117 / 08$ & 22 & 0.763 & $\mathrm{~A}$ & Alluvial fan & Quaternary \\
$8 \mathrm{~A}$ & 55.142 & 36.658 & $66 / 11$ & $322 / 50$ & $164 / 38$ & 12 & 0.934 & $\mathrm{~B}$ & Limestone & Pre-Pliocene \\
$8 \mathrm{~B}$ & 55.142 & 36.658 & $12 / 18$ & $279 / 10$ & $162 / 70$ & 10 & 0.631 & $\mathrm{~A}$ & Limestone & Pre-Pliocene \\
9 & 55.283 & 36.723 & $14 / 3$ & $107 / 45$ & $280 / 45$ & 6 & 0.806 & $\mathrm{~B}$ & Alluvial fan & Quaternary \\
10 & 55.358 & 36.839 & $46 / 03$ & $140 / 50$ & $313 / 40$ & 7 & 0.805 & $\mathrm{~B}$ & Conglomerate & Quaternary \\
11 & 55.429 & 36.874 & $226 / 5$ & $119 / 74$ & $318 / 15$ & 8 & 0.984 & B & Conglomerate & Quaternary \\
\hline
\end{tabular}

Principal stress axes $\left(\sigma_{1}>\sigma_{2}>\sigma_{3}\right)$ and the stress ratio $(R)$, defined as $R=\left(\sigma_{2}-\sigma_{1}\right) /\left(\sigma_{3}-\sigma_{1}\right)$ are presented in this table. $N$ is the number of fault slip planes involved in the stress calculation. Site number 6 is resulted thorough the mentioned "fixed" solution (see text) and is marked by an asterisk. The references for the site numbers are Figures 5 and 6. 
Table 3. Sample characteristics and calculated minimum exposure ages.

\begin{tabular}{cccccc}
\hline Sample ID & Altitude $(\mathrm{m})$ & Latitude $\left({ }^{\circ} \mathrm{N}\right)$ & Longitude $\left({ }^{\circ} \mathrm{E}\right)$ & ${ }^{10} \mathrm{Be}\left(10^{5}\right.$ atoms/g) & Age $(\mathrm{Kyr})$ \\
\hline & & & & & \\
ABR1 & 1706 & 36.69 & 55.08 & $17.69 \pm 1.1$ & $118 \pm 8$ \\
ABR4 & 1678 & 36.69 & 55.08 & $14.19 \pm 0.92$ & $96 \pm 6$ \\
ABR5 & 1683 & 36.69 & 55.08 & $19.22 \pm 1.2$ & $131 \pm 9$ \\
KHI1 & 1433 & 36.64 & 55.27 & $42.07 \pm 2.7$ & $364 \pm 24$ \\
KHI2 & 1432 & 36.64 & 55.27 & $34.16 \pm 2.8$ & $291 \pm 25$ \\
KHI3 & 1442 & 36.64 & 55.27 & $18.58 \pm 1.2$ & $152 \pm 10$ \\
KHI4 & 1438 & 36.64 & 55.27 & $20.32 \pm 1.3$ & $167 \pm 11$ \\
KHI5 & 1437 & 36.64 & 55.27 & $21.96 \pm 1.4$ & $181 \pm 12$ \\
\hline
\end{tabular}

Note: ${ }^{10} \mathrm{Be}$ concentrations analytical uncertainties (reported as $1 \sigma$ ) include a conservative $0.5 \%$ external uncertainty based on long-term measurements of standards, a one sigma statistical error on counted ${ }^{10} \mathrm{Be}$ events, and the uncertainty associated with the chemical blanks correction. Two chemical blanks prepared with the samples yield similar ${ }^{10} \mathrm{Be} /{ }^{9} \mathrm{Be}$ ratio of $3.3 \pm 0.8 \times 10^{-15}$ and $3.4 \pm 0.7 \times 10^{-15}$. For CRE age calculations, a modern sea-level highlatitude ${ }^{10} \mathrm{Be}$ production rate at of $4.5 \pm 0.3$ atoms/g/yr has been scaled for the sampling altitudes and latitudes using the scaling factors proposed by Stone (2000). An additional 6\% production rate uncertainty is considered for CRE age calculation (Stone, 2000). 

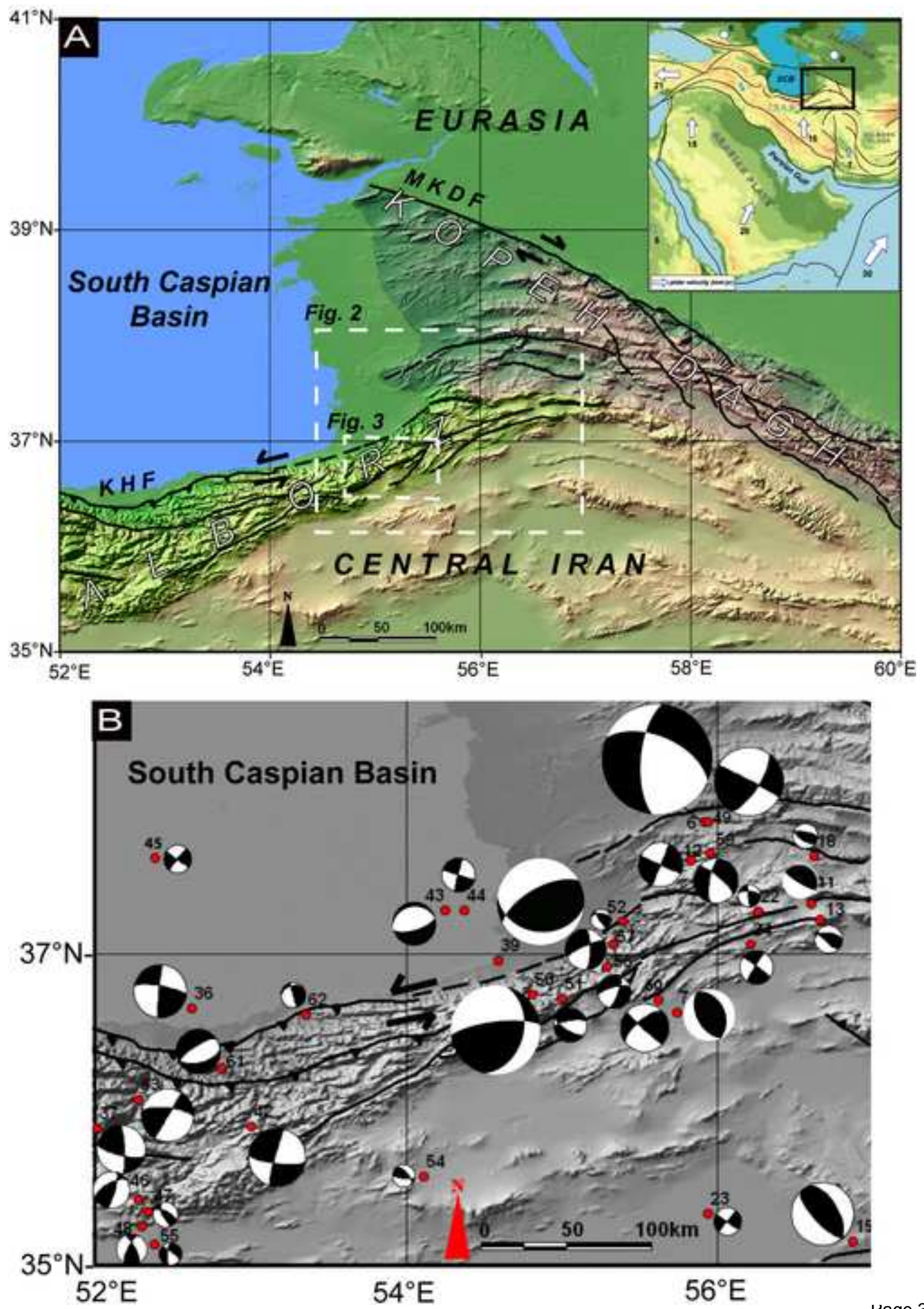


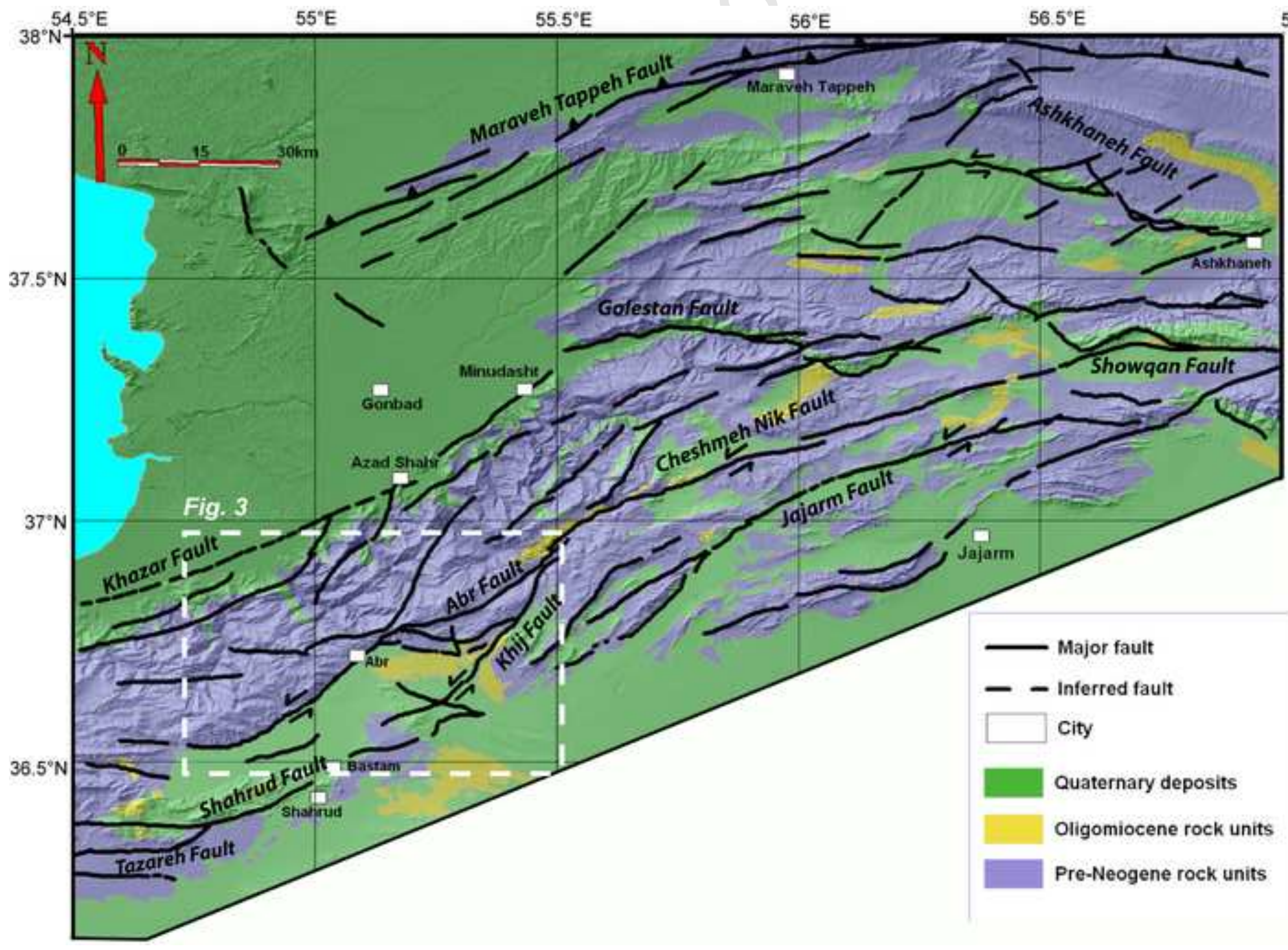

Page 40 of 49 

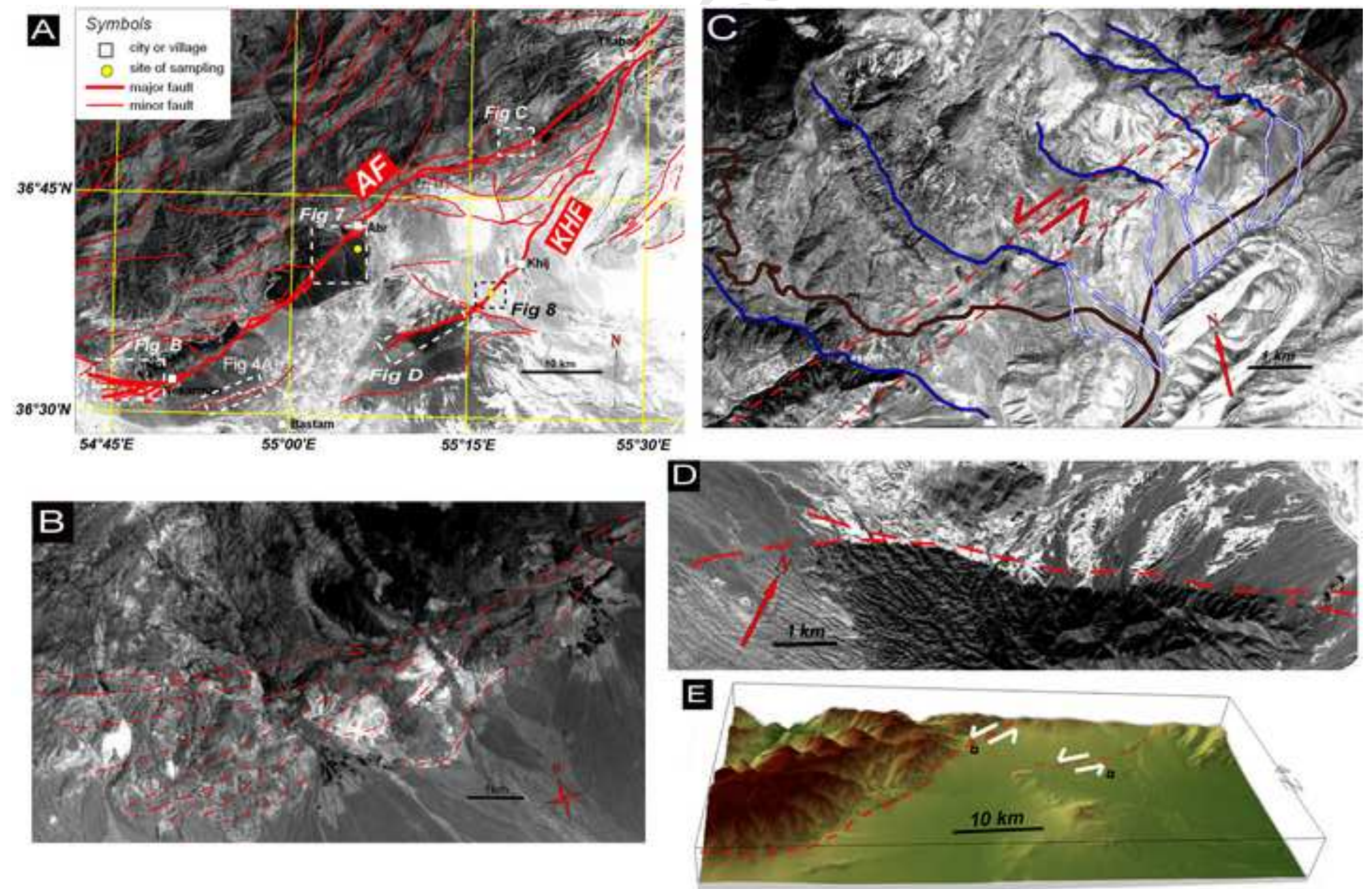

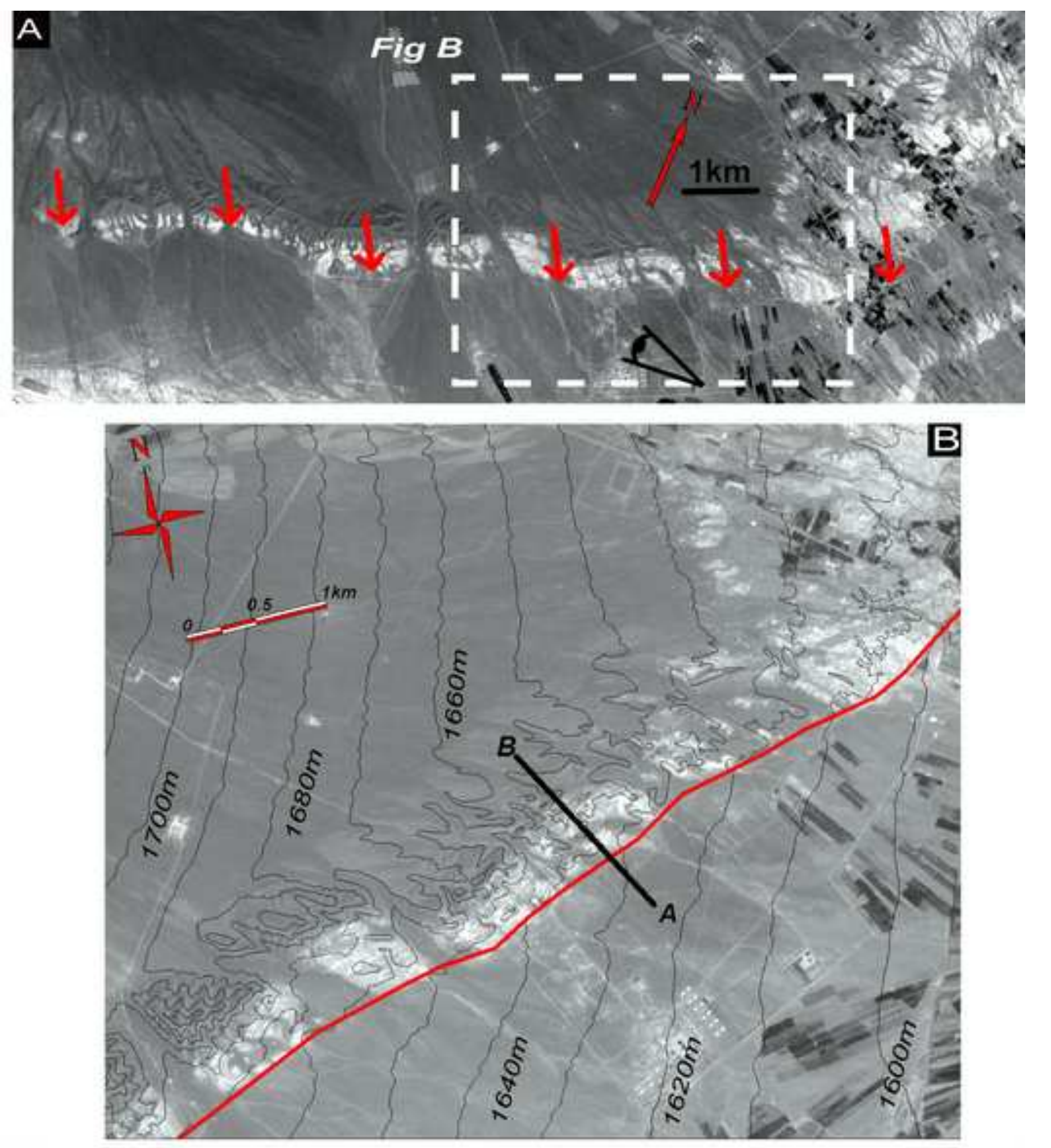

C

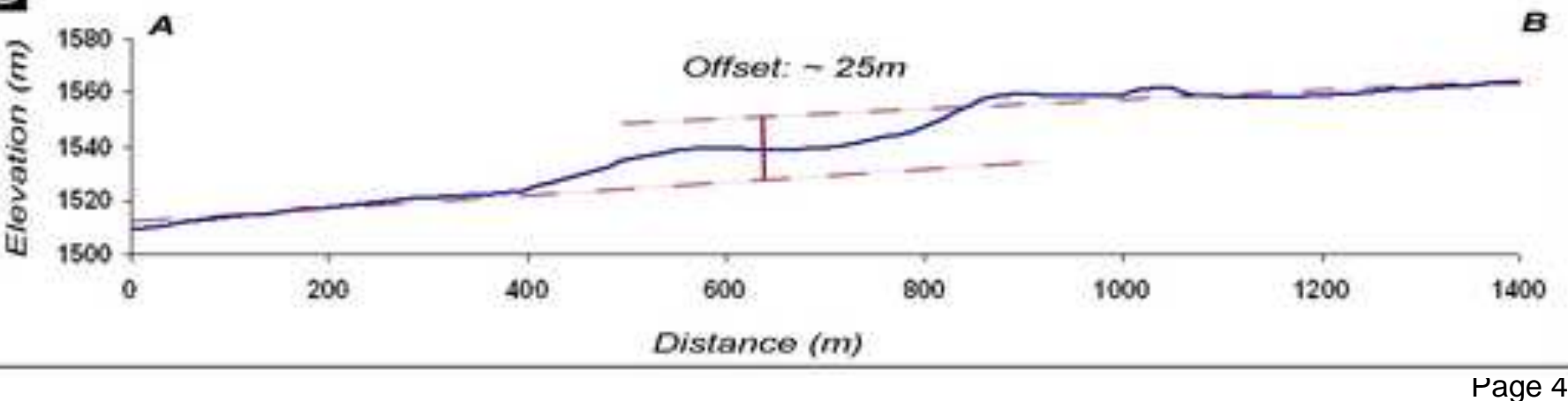

C

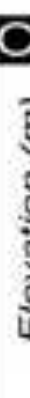
Figure

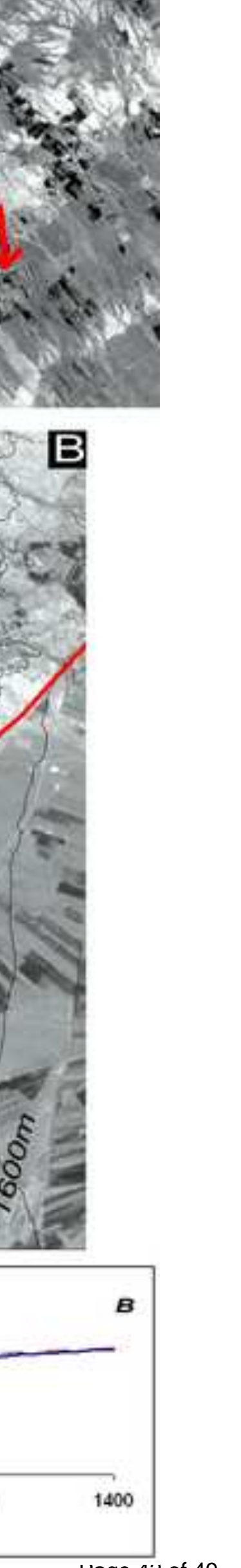




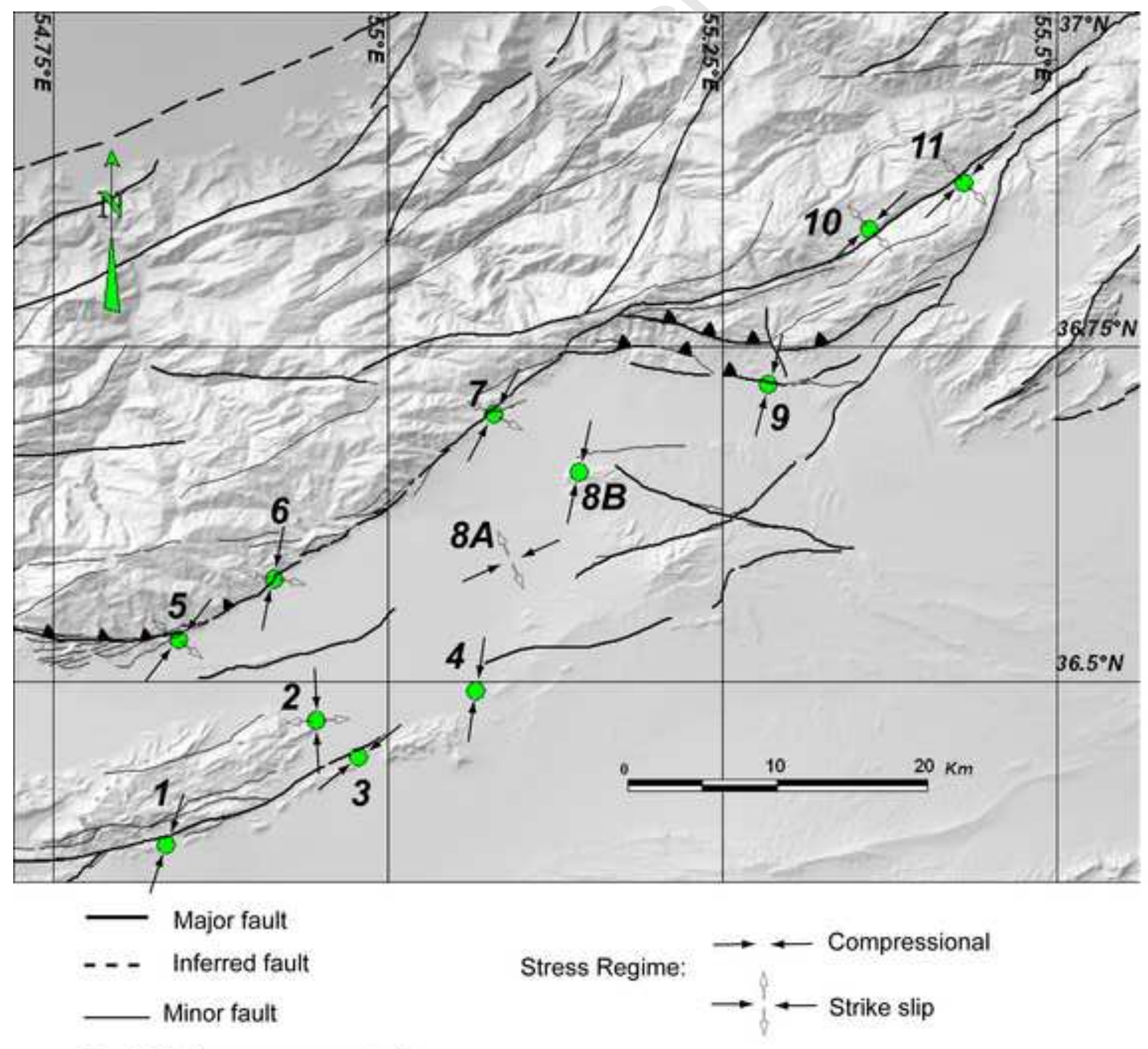

- Striation measurement site 

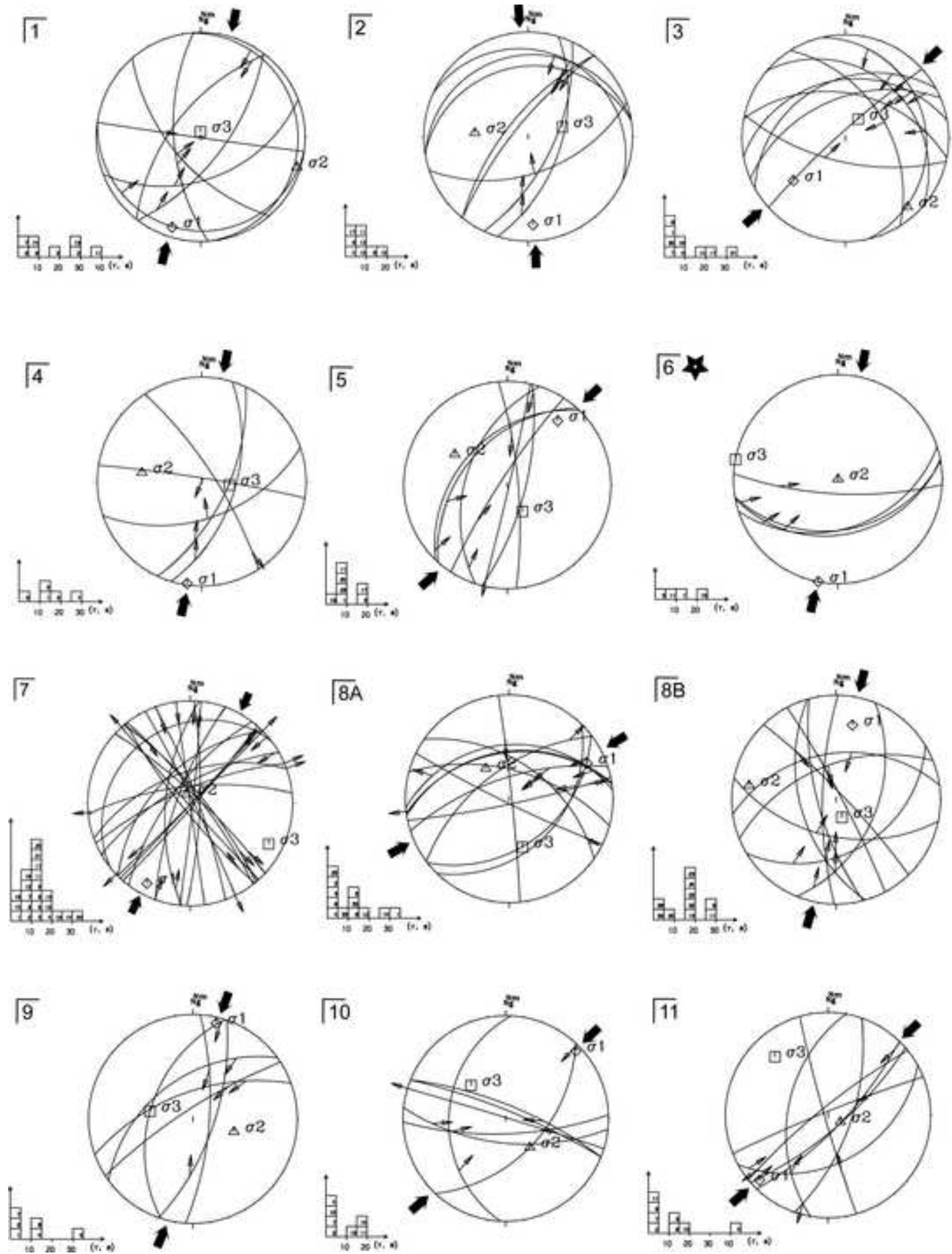

Page 44 of 49 


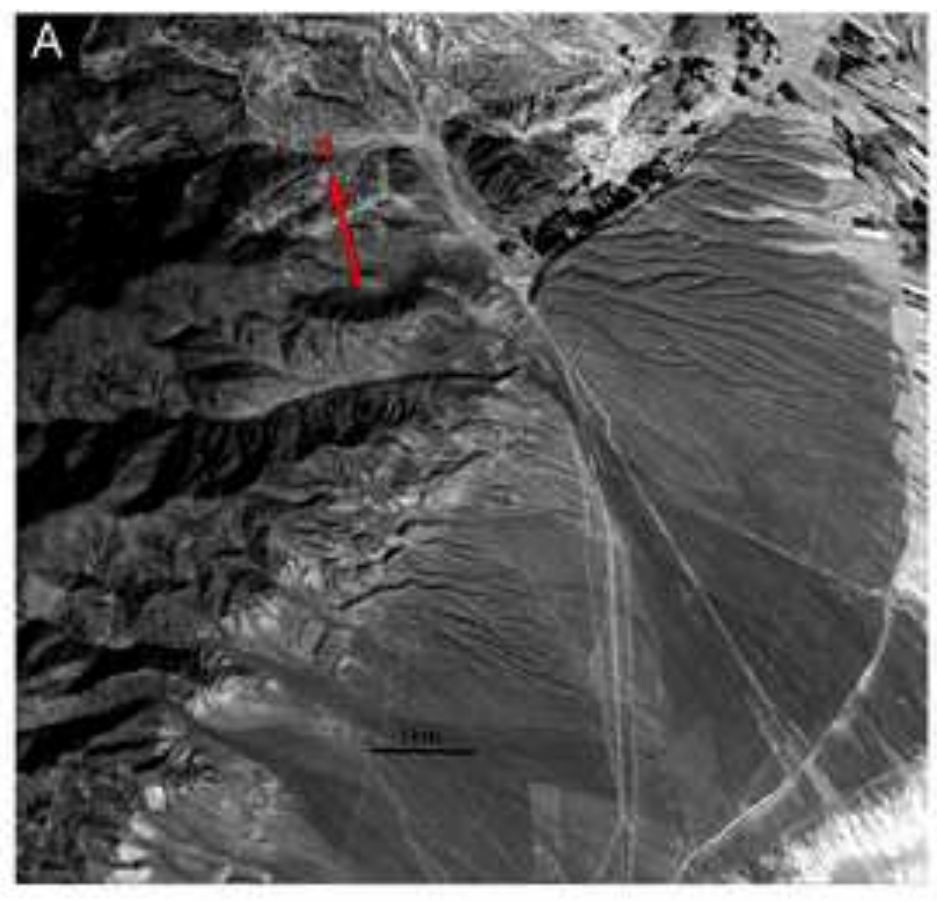

Symbols: fault stream sample Q1 $\quad$ Q2

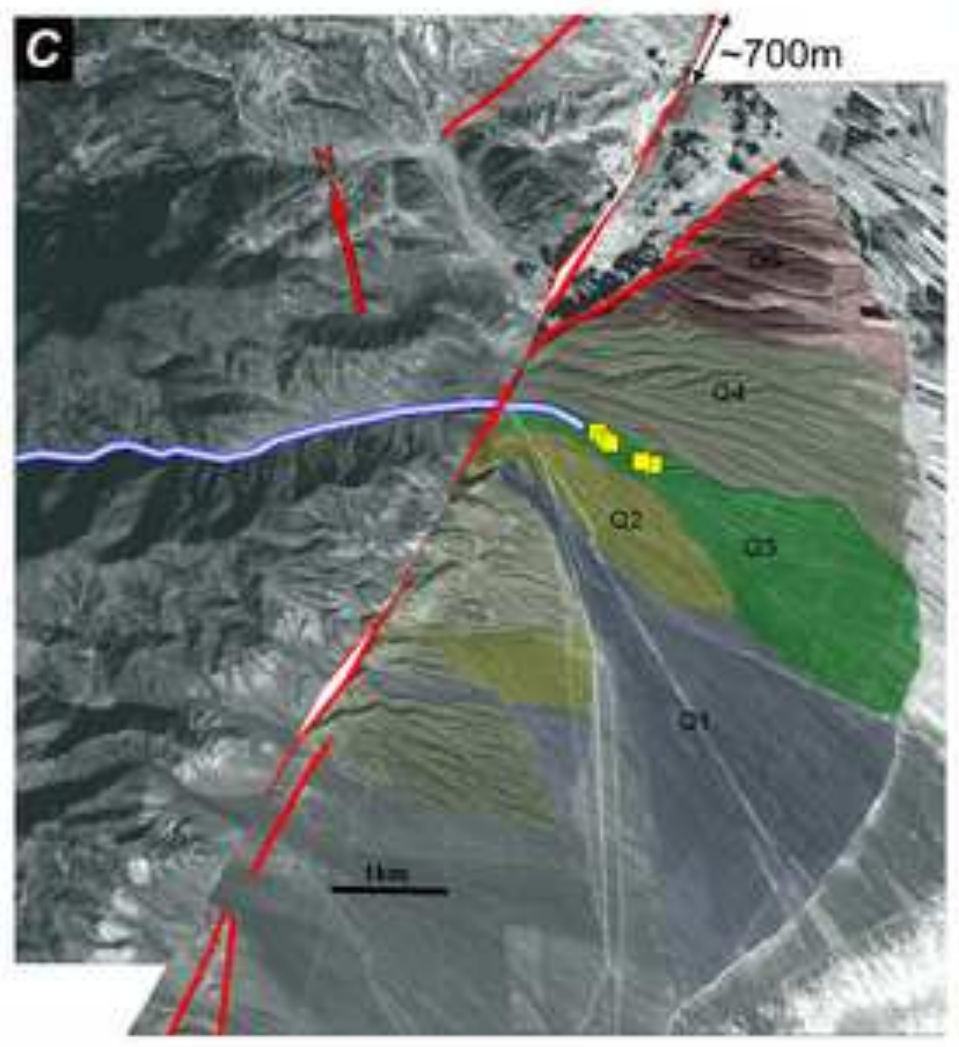

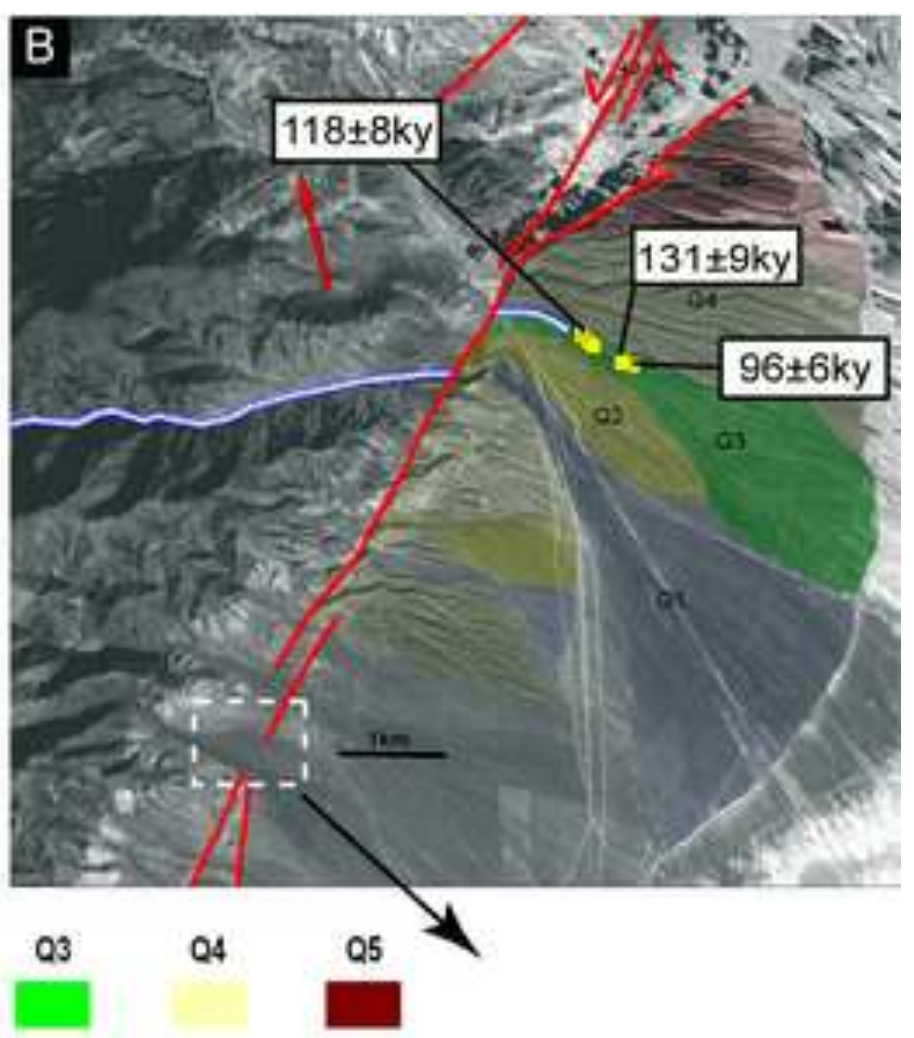
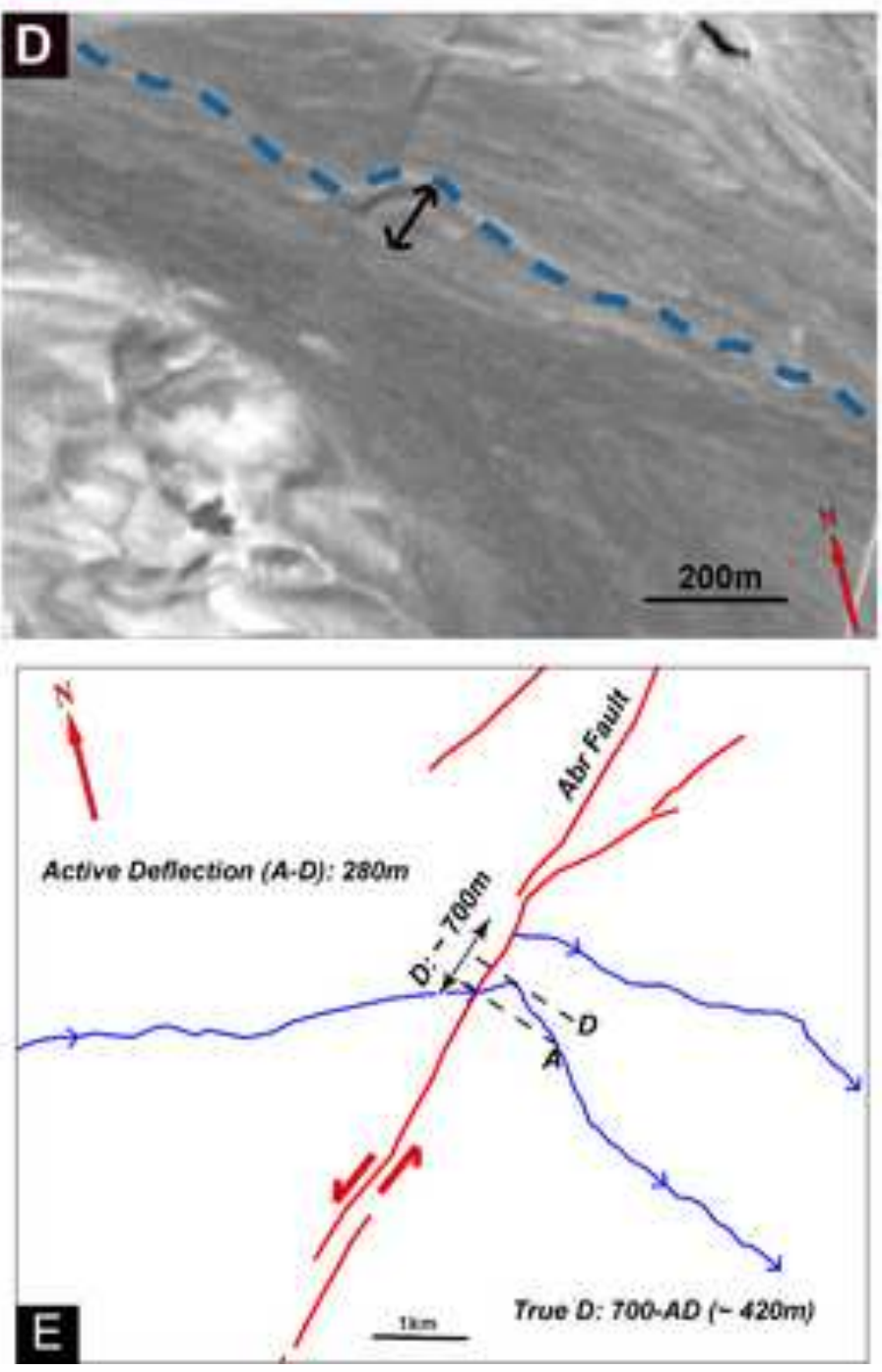

Page 45 of 49 


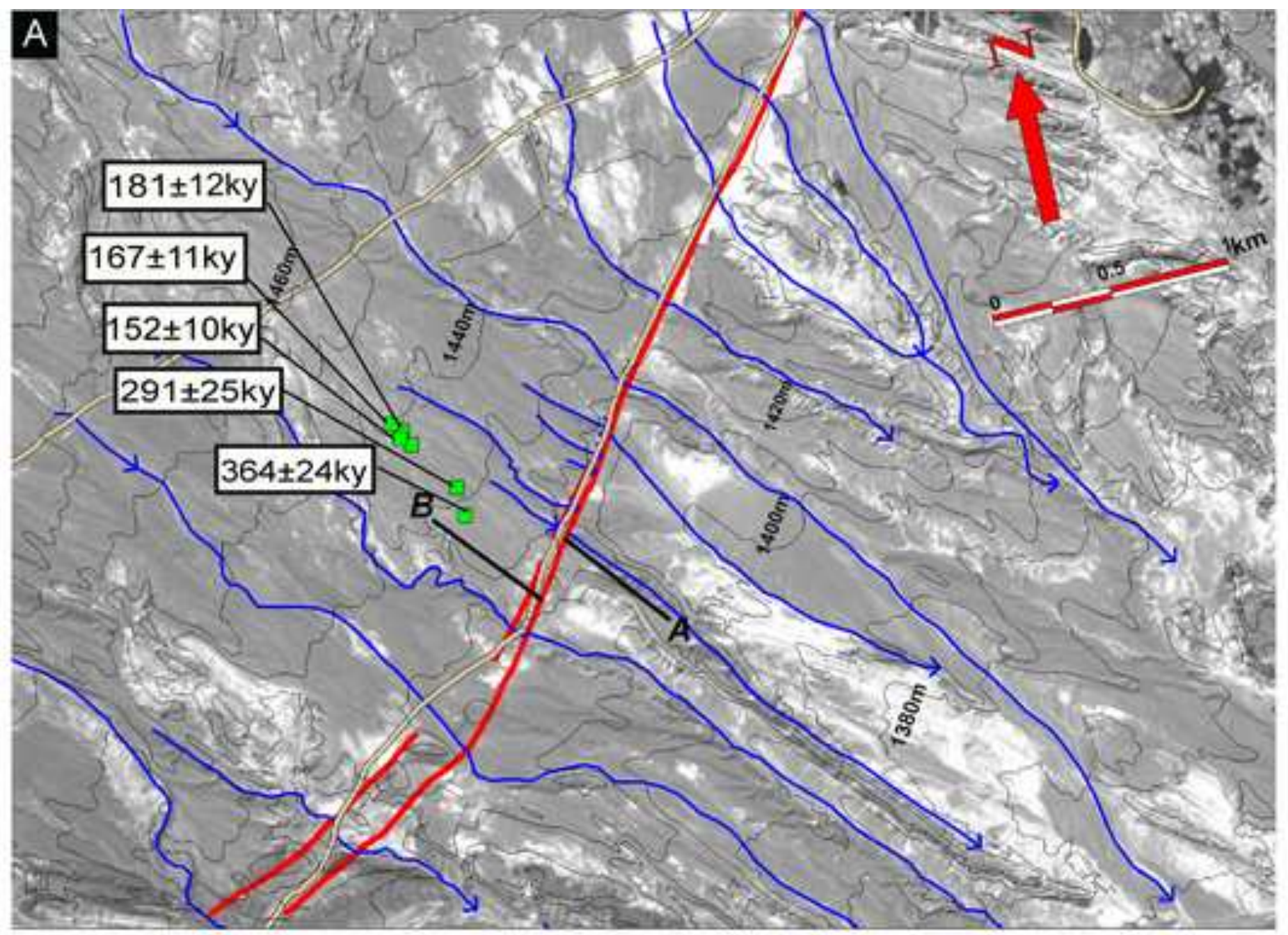

\section{B}

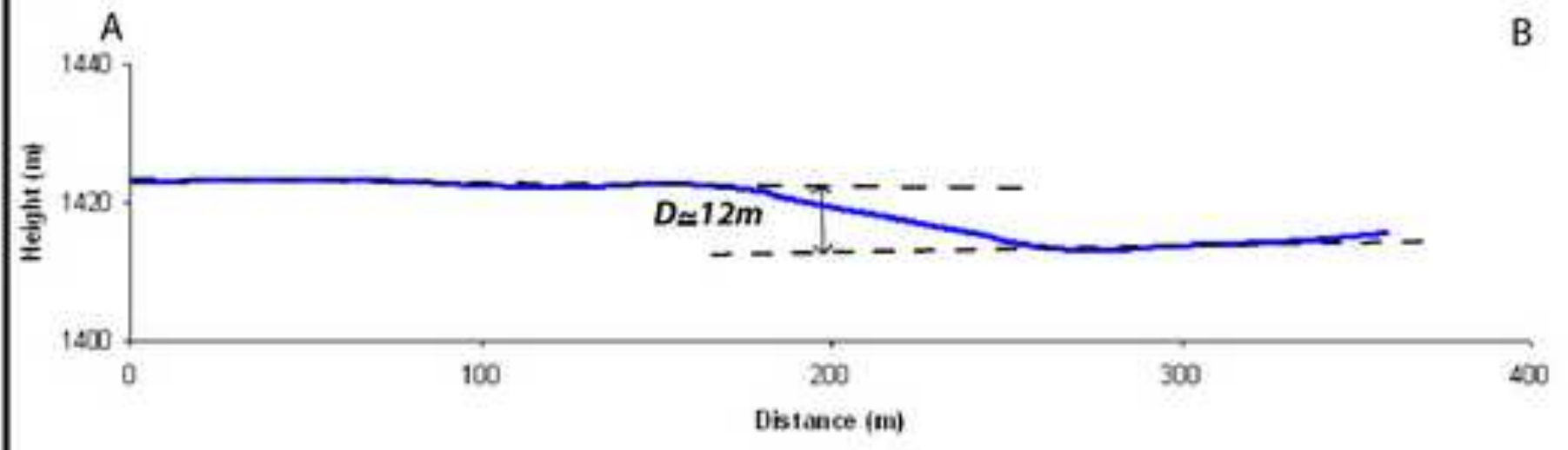



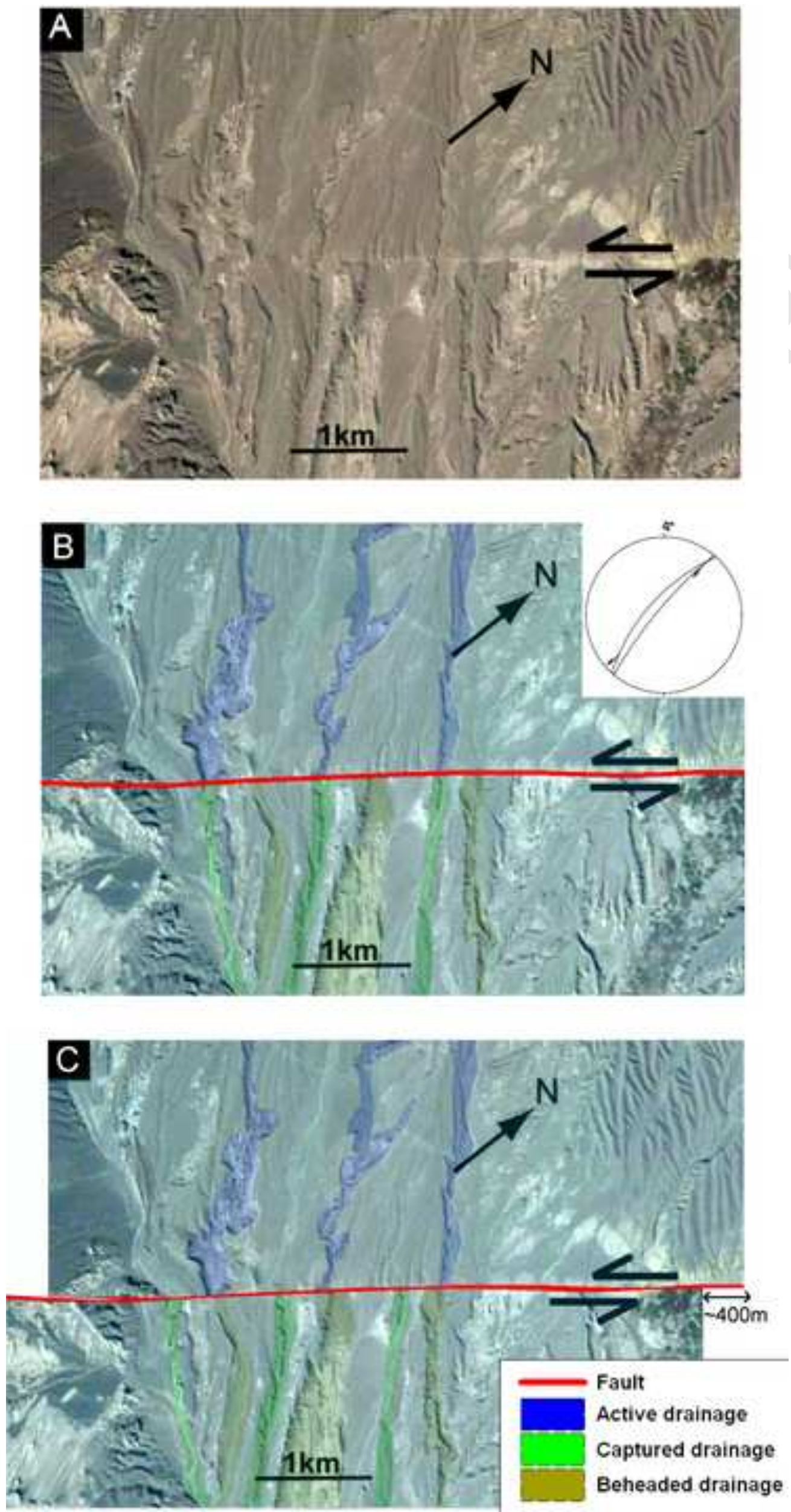

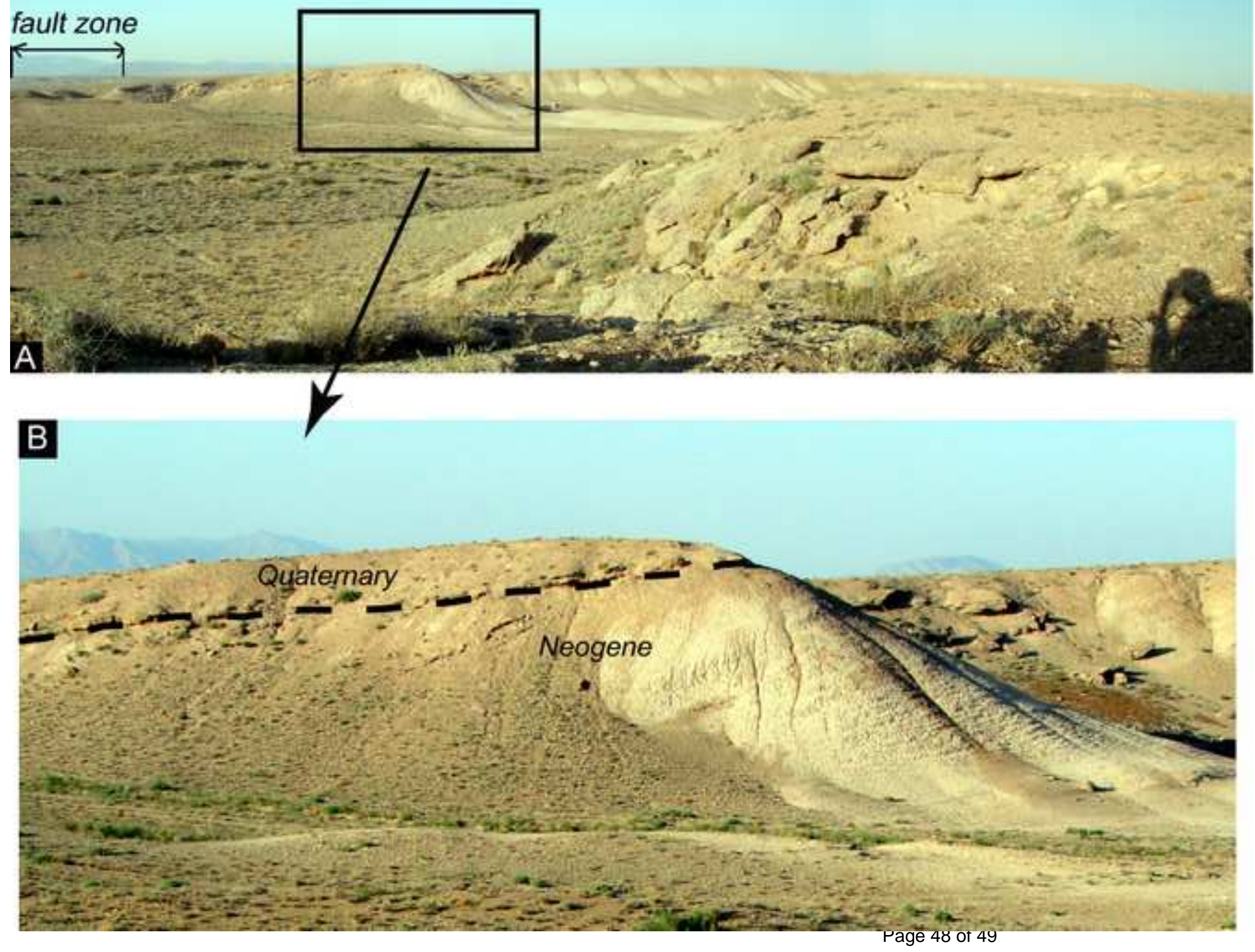


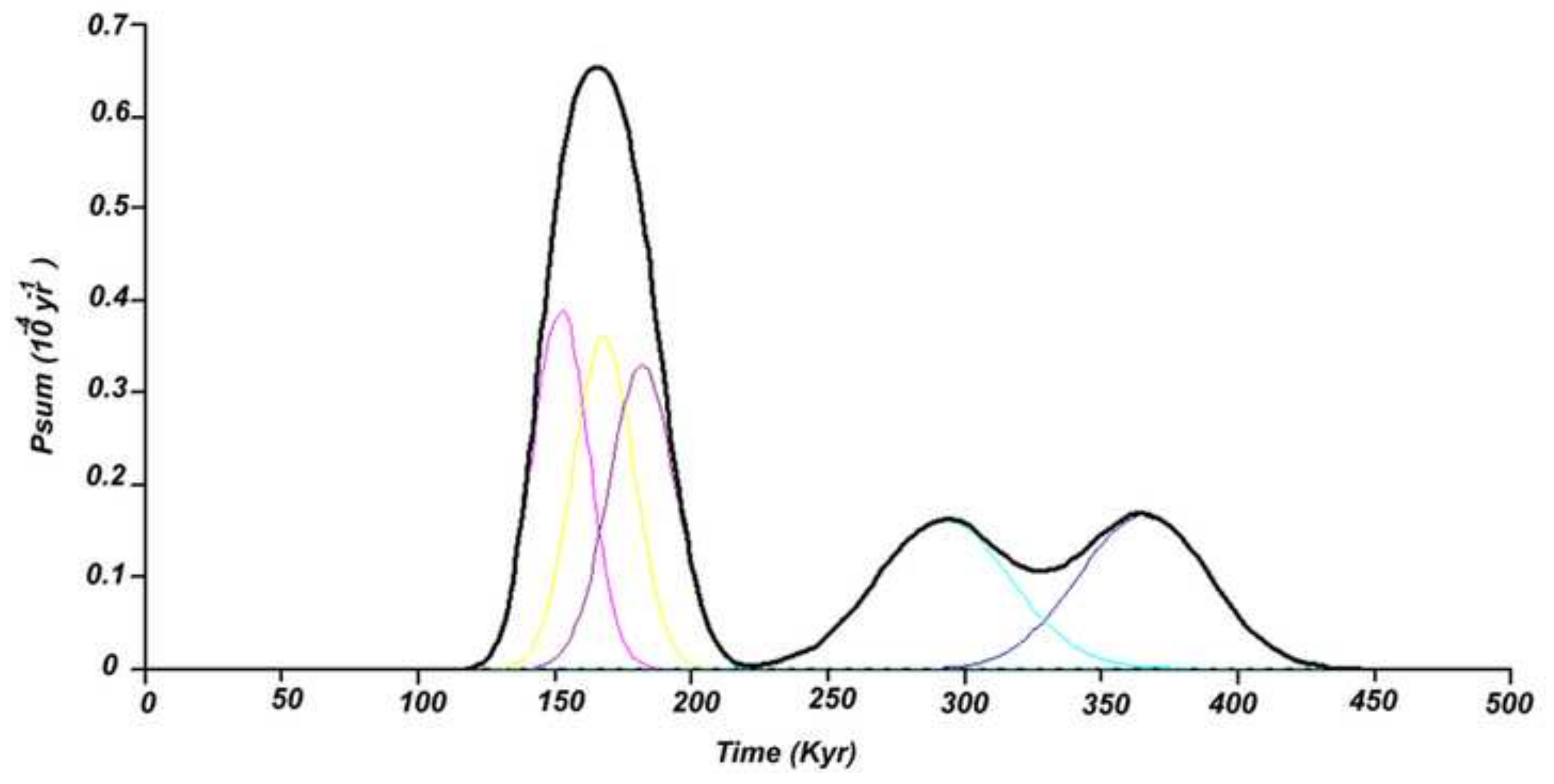

Page 49 of 49 